\title{
The Impact of Heterogeneous Bilateral Investment Treaties (BIT) on Foreign Direct Investment (FDI) inflows to Vietnam
}

\author{
NGUYEN, Thi Viet $\mathrm{Hoa}^{1}$ \\ CAO, Thi Hong Vinh \\ LU, Thi Thu Trang \\ Foreign Trade University
}

May, 2014

\begin{abstract}
The impact of heterogeneous Bilateral Investment Treaties on FDI inflows to a country has been taken into consideration in the world. However, in our perception, only until Bellak and Chaisse (2011), the solution for a BIT index construction could be successfully dealt with. Furthermore, for such a developing country as Vietnam, we couldn't find any previous research regarding this topic. To narrow the gap, we do build up our BIT index for Vietnam basing on the methodology raised by Bellak and Chaisse (2011) for 57 BITs with collected contents. Furthermore, applying Random-effect technique for panel data from 1995 to 2012, we strongly support the positive effect of heterogeneous BITs on FDI inflows to Vietnam. It means signing BIT does help Vietnam to attract more FDI and more favorable BITs lead to further FDI inflows into the country. These results are not only supported by the whole sample but also all, new and old members sample ${ }^{2}$. The commitment and signaling effect of BITs could attribute to the above positive results. Besides the above general effect, as considering the separate impact of each in our 11 main articles, we find out that broadening Definition of Investment, broadening by moving from Admission to Establishment and including National Treatment in BITs give more impetus for investors to carry out FDI flows in Vietnam. Besides, our results also stress on the role of Political Stability and Absence of Violence, Regulatory Quality and Control of Corruption as essential factors of attracting FDI.
\end{abstract}

JEL classification: F21, F36, F53

Key-words: Bilateral Investment Treaty, Foreign Direct Investment, Vietnam

\footnotetext{
${ }^{1}$ The authors would like to give credit to our very important funder of "SECO / WTI Academic Partnership funded by the Swiss Federal Department of Economic Affairs, Education and Research" for our research project.

We also express our sincere thank to Prof. Julien Chaisse for his valuable support of coding BITs and Prof. Christian Bellak for his essential advice for empirical techniques of BIT index construction.

${ }^{2}$ All members sample includes partners having BITs with Vietnam. New members sample considers partners having BITs during the period of 1995-2012. Old members sample looks at partners having BITs signed before the period of 1995-2012.
} 


\section{Introduction}

As a part of International Investment Agreements (IIAs), Bilateral Investment Treaties (BIT) are of countries' most interested and popular investment agreements. According to World Investment Report 2013 made by United Nation Conference on Trade and Development, there have been 2857 BITs in the word by the end of 2012 and each country has signed at least one BIT. In Asia, there are 1194 IIAs involving at least one Asian country which represents almost half of the world total. ${ }^{3}$

However, such important role of BIT and key provisions of these treaties are controversial. Guerin S. (2011) has showed that joining BITs leads to 35\% increase in FDI inflows from European Union to developing countries. In their researches, Busse, M. et. al. (2008), Egger, P. and Pfafferamayr, M. (2004), Neumayer, E. và Spess, L. (2005) and Salacuse, J. and Sullivan, N. (2004) also support the positive correlation between entering BITs and FDI inflows. In contrast, Hallward-Driemeier, M. (2003), Tobin, J. and Rose-Ackerman, S. (2005) find out that BITs have no significant impact or even negative effect on FDI into countries.

According to our research, until the end of 2013, Vietnam has signed 57 BITs with other 56 countries (a BIT with Finland has been adjusted with changes in the main 11 articles). With such many signed and implemented BITs for one country, the actual impact of BITs on FDI into a developing country as Vietnam is of interest. We could see from the below Figure 1 from UNCTAD indicates that FDI to Vietnam has risen drastically. It reaches the value of more than 6000 million USD in 2007 from only around 3000 million in the previous years. In 2008, FDI reached the peak of nearly 10000 million USD. In 2009, FDI reduced but it was higher than the number before 2008. After slightly rising up in 2010 and going down in 2011, the value stood nearly 8000 million USD. With these two upward trends of increasing the number of BIT signed and the value of FDI inflows to Vietnam, we want to see if there could exist any correlation between them. To be more ambitious, we hope to consider the effect of heterogenous BIT on FDI. Our target comes from the fact that despite being based on available forms of

\footnotetext{
${ }^{3}$ Chaisse Julien (2014) The Investment Version of Asian Noodle Bowl-- Proliferation of International Investment Agreements, Asian Development Bank Working Paper No.128, May 2014 (75 p.) [http://aric.adb.org/pdf/workingpaper/WP128_Hamanaka_Investment_Noodle_Bowl.pdf ]
} 
regulations, BITs are still different from each other to some extent, making it less or more favorable among them.

Although the question regards heterogeneous BITs and their impacts on FDI is quite interesting, in our perception, there has been no research focusing on the impact of BITs, especially no detailed and focused analysis of BITs' key provisions on FDI inflows to Vietnam. In our research, we expect to narrow the gap for such impact (BITs and BITs' key provisions on FDI inflows).

Figure 1: Foreign Direct Investment into Vietnam for the period of 1995-2012 Unit: Million USD*

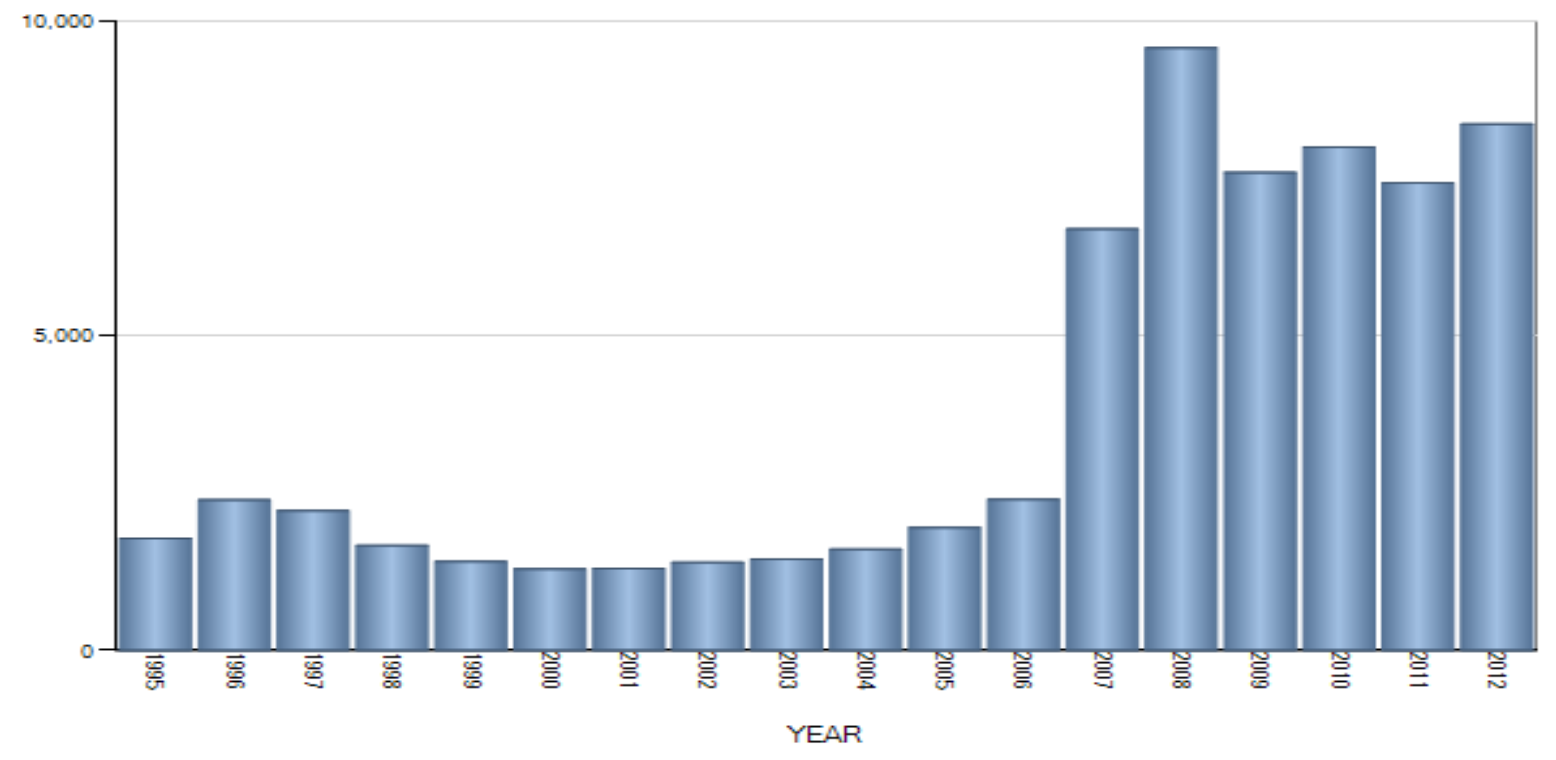

(* in current price and exchange rate)

Source: UNCTAD Online-Statistic Database

To narrow the gap, we do research on the effect of heterogeneous BITs on FDI inflows to Vietnam for a large sample covering 71 partners for the period from 1995 to 2012 and affirms that signing BIT does help the country to attract more FDI and more favorable BITs lead to higher FDI. This effect is even larger as sub-samples of partners (i) having BITs with Vietnam (all members), (ii) having BITs during the period of 19952012 (new members) and (iii) having BITs before the period of 1995-2012 (old members). More over, we also find out that among 11 articles, the three including Definition of Investment, Admission vs. Establishment and National Treatment do positively affect FDI investors once they become more favorable.

The remainder of the paper is organized as follows. Section 2 presents the literature review. Section 3 regards the data. Next section is about the empirical 
strategies. Section 4 shows the main results and robustness checks. The final section is the conclusion.

\section{Literature review}

Regarding the effect of BITs on FDI between and within countries, it is perceived that many studies have been carried out. To review what have been done, we summarize the main findings fot the following questions:

- Do BITs positively or negatively affect FDI?

- Are there any differences in the impact on FDI for BITs with various levels of liberalization and protection (called heterogeneous BITs)?

- How can the dissimilarity of BITs' levels of liberalization and protection be measured?

- How about researches about Vietnam?

\section{Do BITs positively or negatively affect FDI?}

Despite the enormous number of signed BITs among countries across time, the real effect of these treaties on FDI is still questionable. On the one hand, studies of many authors support the positive impact of BITs. In particular, Busse (2010), applying a gravity model with instrument approach, has shown that BITs do help to push up FDI inflows to developing countries and BITs even substitute for week domestic institutions. According to Neumayer and Spress (2005), a larger number of BITs leads to the higher FDI inflows to developing countries. These authors also show the evidence of BITs as a substitute for a favorable local business environment. In his recent research, Bellak (2013) from a policy point of view indicates that the influence of BITs on FDI attracts further attention. The reasons he includes are (i) the sharp increase of State-investor dispute $^{4}$ and (ii) the rising inclusion of investment chapters in new regional trade agreements. With regard to the channels through which BITs affect positively FDIs, UNCTAD (2009) clarifies the positive effect of BIT via four mechanisms of (1)

\footnotetext{
${ }^{4}$ See for instance the rise of investment claims against Asian states, Chaisse, Julien (2013) Assessing the Exposure of Asian States to Investment Claims (2013) 6(2) Contemporary Asia Arbitration Journal 187225.
} 
commitment effect, (2) signaling effect ${ }^{5}$, (3) shortcut to improved institutional quality ${ }^{6}$ and (4) stronger BITs in terms of dispute settlement have greater impact on FDI. Wälde (2005) and Allee and Peinhardt (2011) regard BITs as a credible commitment device especially from the perspective of the possible assess to international arbitration for foreign investors, hence leading to the growth of FDI. Vandevelde (1998), HallwardDriemeier (2003) and Elkins et al. (2006) also point out the commitment effect through which the time-inconsistency problem could be solved, hence, pushing up the FDI inflows. Besides the commitment channel, Elkins et al. (2006) applies a competitive model to clarify the reasons for the expectation of higher FDI. In their point of views, in order to gain reputational advantage and get out of the possible competition with other host countries which also struggle to attract the similar types of FDI, it is rational for an individual country to seek for signing BITs. Jandhyala and Weiner (2012) support the positive effect of BITs thanks to its bringing greater certainty about future treatment of assets of the host countries, encouraging investors to carry out further investment.

From a different perspective, on the other hand, there are also not few researches presenting no or little effect of BITs on FDI. UNCTAD (2003) mentions a possible minor role of BITs as well as IIAs in influencing FDI flows due to the fact that it is not easy to isolate the impact of BITs with other factors as the interaction and relative importance of individual determinants are more and more increasing. Tobin and Rose-Ackerman (2005) find no significant effect of BITs on FDI except for the case of low level political risk. Tobin and Rose Ackerman (2011) add that it's the surge in BITs weakening the role of the treaties as a tool for FDI attraction to a specific country. In his study using Meta methodology, Bellak (2013) shows that the marginal effect of a single BIT diminishes as the number of BITs goes up, causing low or statistically insignificant effect sizes. Moreover, Aisbett (2009) explains for the finding that the BIT impact is not observed empirically. The argument comes from the absent commitment effect of BIT originating

\footnotetext{
${ }^{5}$ Kerner (2009) defines signaling in the case of BITs and FDI to be sending a broadly received signal that a country is trustworthy. This will update the investors' belief about the reduction of information asymmetry once BITs are signed or ratified.

${ }^{6}$ For further clarification, we think that BITs not only provide protection, but also it makes contribution to institutional quality as well. From the investors' perspective, BITs protect investors especially in the cases of weak institutional quality. This point is supported by Busse et. al. (2008). In addition to this, in our points of view, from host countries' perspective, BITs do play the role of institutional quality itself as it also contributes to the improving policy framework of the country..
} 
from the given government behavior, repeated games between investors and governments, reputation effects. Hallward-Driemeier (2003) in their research find little evidence about the significant role of BITs on FDI flows to developing countries from OECD countries. This point is also presented by Min et. al. (2011) using random coefficient panel model. They confirm the finding of no statistically impact of BITs for the period following Asian Financial Crisis, implying the less importance of this type of agreements. They even stress on the less effect size for developing countries compared with that for developed countries.

Are there any differences in the impact on FDI for BITs with various levels of liberalization and protection?

Although a variety of BITs-on-FDI researches have been conducted as mentioned above, many of them treat BITs relatively equally, meaning that the variation in levels of liberalization and protection of different BITs is not taken into considerationconsideration; hence BITs are regarded to be homogenous. This is in doubt because of the fact that BITs with different partners will have not the similar important level to participating countries' economies, especially FDI (called heterogeneous BITs). To make clear this point, in their research, Salacuse and Sullivan (2005) show that BITs of some countries with the United States are stricter than with other OECD countries. Swenson (2005) explains for no or little impact of BITs in the previous findings. In his point of view, it's the generalization in the cross-country analyses making it impossible to capture the full heterogeneity of BITs. According to Hallward-Driemeier (2003), the nature of commitment through which BITs affect FDI depends on the terms included in these agreements. The author points out the attention of researchers to be put just on the existence of BITs, but not much on the strengths of clauses, such as property rights. Moreover, Busse (2010) indicates the more binding trend of BITs and recent agreements seem to be more effective than the older ones in attracting FDI inflows. In his study, Bellak (2013) states about the lack of earlier literature about BITs' heterogeneity, hence the information behind the average effect will not make much sense for policy maker. He indicates the trend that investor care more about the quality of BITs in their location decisions, hence it is important to do researches about the quality, rather than quantity 
aspect of $\mathrm{BITs}^{7}$. He also stresses about the larger effect sizes for the BITs with visible arbitration clauses. Furthermore, the idea about the heterogeneity of BITs is further supported by Jang (2011), who has indicated that the higher level of liberalization a BIT has, the larger amount of FDI inflows are attracted into the developing countries in Eastern, Southern and Southeastern Asian countries from 22 OECD economies during the 1985-2009 period. He does summarize two mechanisms of the effect, which are commitment and signaling effect. According to Jang (2011), the heterogeneity of BITs is considered by looking into the main articles of agreements. For example, regarding investment definition clause, the investment liberalization coverage for recent BITs is extended to the pre-establishment, which means barriers for investors' investment will be lifted at the entry phase. Relating to treatment-clauses, the BIT between Australia and the Philippines (ratified in 1995) includes only Most Favored Nation (MFN) treatment, while that between Australia and Vietnam (enforced in 1991) is comprised of both MFN and National Treatment (NT). About one of the more and more important clause, investorstate dispute settlement, only new BITs but not the older ones contain such provision. Berger et. al. (2010) also agrees with the vital role of investor-state dispute settlement clause. He mentions that informed foreign investors will not react in the resemble way to BITs with and without that clause. The creditability of investors comes from the fact that their investments will be protected against host countries' violation. Kerner (2009) even finds that it's the dispute settlement clause attributing to the promoting FDI role of recent BITs, but not the older ones. From all of these above points, it is reasonable to take heterogeneous BITs into further account.

\section{How can the dissimilarity of BITs' levels of liberalization and protection be}

\section{measured?}

Developing BIT index from the basic dummy variable with 0 and 1, researchers have tried to quantitatively account for the heterogeneity of BITs. However, given the perception of heterogeneous BITs, the measurement for these is still unsatisfied until Bellak and Chaisse (2011). According to Jang (2011), there is no previous study before his research to create an index of BIT (in spite of the proliferation of that for regional

\footnotetext{
${ }^{7}$ For Bellak (2013), quantity aspect of BITs is considered by counting BITs, while quality regards the legal heterogeneity of BITs.
} 
trade agreements ${ }^{8}$ ). He makes an improvement in constructing a BIT index. However, what he has done is just scoring provisions on subjective choice and then taking simple average. BIT selection index which is on the way of setting up by Bellak and Chaisse (2011) is among the most updated and of interest because at first it covers a relatively wide range of main provisions in BITs (11 provisions). Moreover, unlike the subjectively appointing values to clauses, the authors consider weights for each of the provisions by applying factor analysis. This is considered a big progress in BIT index construction.

\section{How about researches about Vietnam?}

In our perception, until now, there are few papers to consider the impact of BITs on FDI. That effect is somehow taken into consideration as a supplement for other main results. Cao (2013) as looking into the impact of Vietnam's WTO membership on FDI presents the effect of BITs. She finds the positive influence of BITs between Vietnam and its partners on FDI. However, the variable of BIT is just a dummy, which couldn't help to clarify the difference in the levels of liberalization and protection of BITs. So far we couldn't find any paper constructing a BIT index for Vietnam.

\section{Data}

\subsection{BIT index}

The process of BIT index construction includes 2 main parts of (i) coding each article of BIT and (ii) applying Principal Component analysis to obtain the final index.

At first, for coding articles, we take into consideration the suggested main ones from Bellak and Chaisse (2011) including Definition of Investment, Admission vs. Establishment, National Treatment, Most Favored Nations, Fair and Equitable Treatment, Direct and Indirect Expropriation, Free Transfer of Investment-related Funds, NonEconomic Standards, Investor-State Dispute Settlement, Umbrella Clause and Temporal Scope of Application. ${ }^{9}$ We based our analysis on collected 57 BITs which Vietnam has

\footnotetext{
${ }^{8}$ According to Jang (2011), the liberalization of regional trade agreements is measured by constructing indexes. Adams et. al. (2003) set the value of index to be 1 for agreements with investment provision prohibiting restrictions on investment, 0.75 for ones containing national treatment, 0.25 for ones including initiatives to reduce restrictions and facilitate investment and 0 for no investment chapter. That way of setting particular values is also applied by some other researchers.

${ }^{9}$ For a definition of each of these concepts, see 'Exploring the Confines of International Investment and Domestic Health Protections - General exceptions clause as a forced perspective' (2013) 39(2/3) American Journal of Law \& Medicine 332-361.
} 
signed with 56 different countries. There is one case of amended BIT (Finland) with changes in any of those above articles in comparison with the original. We have regarded that as a new BIT, meaning it will be analyzed separately with its original.

The code for each article is comprised of two values of 1 and 2 . The exact meaning for 1 or 2 is described in details in Appendix 1, but in general, 2 shows more favorable condition for investors than 1 . Table 1 presents summary statistics of articles in the BIT sample with 57 BITs. From this table, it could be seen that Article 4 (Most Favored Nations) is available in all BITs, leading to no variation at all. As a result, this article isn't used for BIT construction, but we still take advantage as looking at the separate impact of each article on FDI inflows to Vietnam. See also Table 2 for correlation among pair-wise articles in the BIT sample.

Table 1: Summary Statistics of Articles in the BIT sample (57 BITs are considered)

\begin{tabular}{|c|c|c|c|c|c|}
\hline Variable I & Obs & Mean & Std. Dev. & Min & Max \\
\hline $\begin{array}{l}\text { article1 } \\
\text { article2 } \\
\text { articles } \\
\text { article4 } \\
\text { articles }\end{array}$ & $\begin{array}{l}57 \\
57 \\
57 \\
57 \\
57\end{array}$ & $\begin{array}{r}1.22807 \\
1.017544 \\
1.368421 \\
2 \\
1.982456\end{array}$ & $\begin{array}{r}.4233178 \\
.1324532 \\
.4866643 \\
0 \\
.1324532\end{array}$ & $\begin{array}{l}1 \\
1 \\
1 \\
2 \\
1\end{array}$ & $\begin{array}{l}2 \\
2 \\
2 \\
2 \\
2\end{array}$ \\
\hline $\begin{array}{c}\text { article6 } \\
\text { article7 } \\
\text { articles } \\
\text { article9 } \\
\text { article10 }\end{array}$ & $\begin{array}{l}57 \\
57 \\
57 \\
57 \\
57\end{array}$ & $\begin{array}{l}1.912281 \\
1.596491 \\
1.964912 \\
1.912281 \\
1.368421\end{array}$ & $\begin{array}{l}.2854008 \\
.4949621 \\
.1856372 \\
.2854008 \\
.4866643\end{array}$ & $\begin{array}{l}1 \\
1 \\
1 \\
1 \\
1\end{array}$ & $\begin{array}{l}2 \\
2 \\
2 \\
2 \\
2\end{array}$ \\
\hline article11 & 57 & 1.736842 & .4442617 & 1 & 2 \\
\hline
\end{tabular}

Table 2: Correlation of Articles in the BIT sample

article1 article2 article3 article5 article6 article7 article8 article9 artic 10 artic 11

\begin{tabular}{r|rrrrrrrrrr} 
article1 & 1.0000 & & & & & & & & & \\
article2 & 0.2458 & 1.0000 & & & & & & & & \\
article3 & 0.1916 & 0.1750 & 1.0000 & & & & & & & \\
article5 & -0.2458 & 0.0179 & -0.1750 & 1.0000 & & & & & & \\
article6 & 0.0207 & 0.0414 & 0.1083 & -0.0414 & 1.0000 & & & & & \\
article7 & 0.1062 & -0.1625 & 0.3316 & -0.1099 & 0.1242 & 1.0000 & & & & \\
article8 & -0.1236 & -0.7008 & -0.2497 & -0.0255 & 0.2779 & 0.2319 & 1.0000 & & & \\
article9 & 0.0207 & 0.0414 & -0.0203 & -0.0414 & -0.0962 & -0.1286 & -0.0591 & 1.0000 & & \\
article10 & 0.3650 & -0.1021 & 0.0952 & -0.1750 & 0.1083 & 0.2575 & 0.1456 & -0.1489 & 1.0000 & \\
article11 & 0.0400 & 0.0799 & 0.1261 & -0.0799 & -0.0445 & 0.0769 & -0.1140 & -0.0445 & 0.1261 & 1.0000
\end{tabular}


After the phase of coding articles, the methodology of Principal Component analysis $(\boldsymbol{P C A})^{10}$ has been applied. The brief methodology analysis is considered in Appendix 2. The rationale for using this method is that we could find out the different components, each of which contains the underlying information about how it can explain the change in variables of articles (variance). Or in another way of interpretation, we could say about the composition of different variables (weights) in each component.

Based on the value of eigenvalue (which is bigger than 1 with 5 components) across components shown in Figure 2, we decided to select 5 components for our data analyses. Table 3 demonstrates that the variations of our 10 articles in the sample (except Article 4 of Most Favored Nation) are explained largely of more than $50 \%$ by our 5 components (the value of "unexplained value" is small than 0.5 for all articles). With the exact values for these 5 components (ranging from -1 to 1) provided by PCA representing 5 types of weights, we take the simple average to have our one value of weight (initial BIT index). Finally, we rescale our values to get the final BIT index ranging from slightly above $0^{11}$ to 1 . The higher value of BIT index implies the more favorable conditions for investors.

Figure 2: Value of eigenvalue across components after Principal Component Analysis

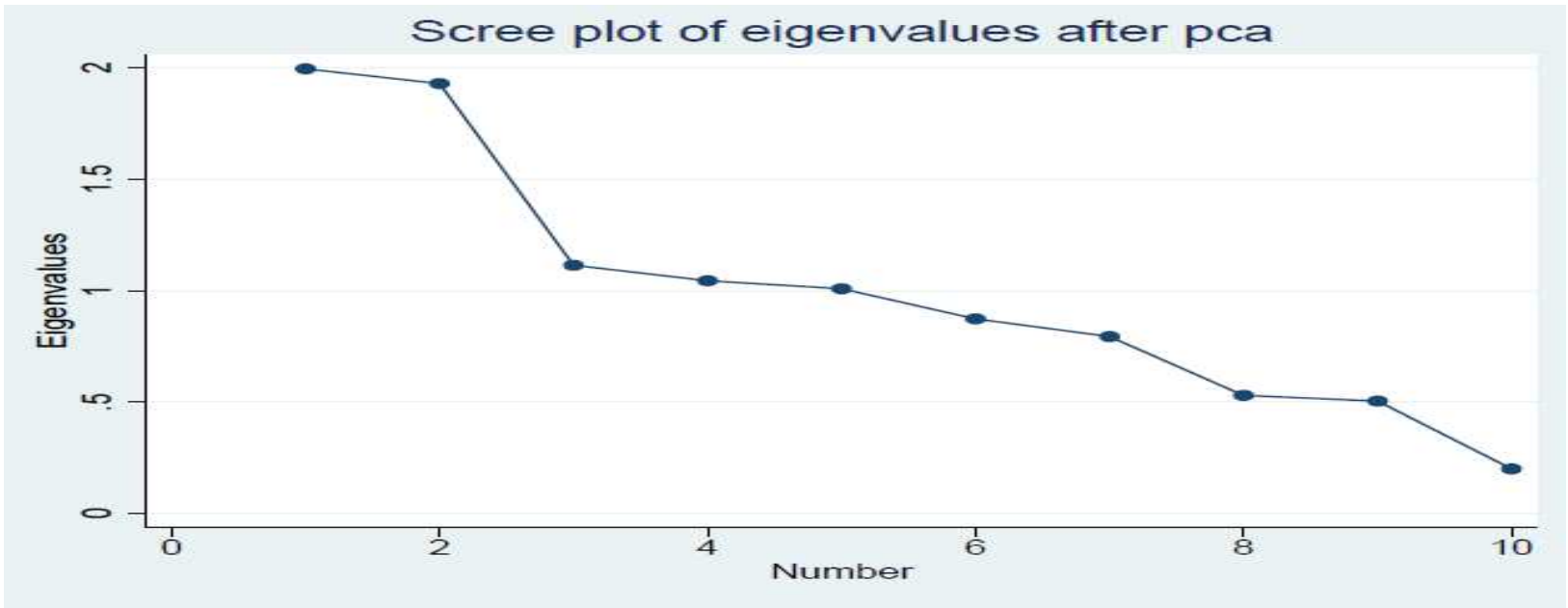

\footnotetext{
${ }^{10}$ Factor Analysis rather than Principal Component Analysis is the method suggested by Prof. Bellak. However, we find Principal Component more suitable for our data and objective of considering deeply the values of components based on the observable articles.

${ }^{11}$ This is necessary to distinguish with the case of no BIT that we will consider in our database later. We do rescale by subtracting the original value by the minimum, then plus a small value of 0.01 . This overall value is divided with (maximum+0.01-minimum).
} 
Table 3: Role of each components in explaining the variation of each article suggested by Principle Component analysis

\begin{tabular}{|c|c|c|c|c|c|c|}
\hline Variable | & Comp1 & Comp2 & Comp 3 & Comp4 & Comp5 & Unexplained \\
\hline $\begin{array}{l}\text { article } 1 \\
\text { articlee } \\
\text { articles } \\
\text { articles } \\
\text { articlee } \\
\text { article } \\
\text { articles } \\
\text { article } \\
\text { articlel } \\
\text { articlell }\end{array}$ & $\begin{array}{r}0.1795 \\
0.6661 \\
0.1845 \\
0.1021 \\
-0.0031 \\
-0.2465 \\
-0.6290 \\
-0.0174 \\
-0.1506 \\
0.0111\end{array}$ & $\begin{array}{r}0.6704 \\
0.0693 \\
-0.0497 \\
-0.4066 \\
0.0217 \\
0.0151 \\
0.0333 \\
-0.0444 \\
0.6113 \\
0.0218\end{array}$ & $\begin{array}{r}-0.0596 \\
0.0210 \\
0.7052 \\
-0.1731 \\
0.1988 \\
0.5982 \\
-0.0416 \\
0.0111 \\
-0.0230 \\
0.2626\end{array}$ & $\begin{array}{r}-0.0776 \\
0.0620 \\
-0.0986 \\
0.3978 \\
0.1722 \\
0.0844 \\
0.0100 \\
-0.8128 \\
0.2583 \\
0.2406\end{array}$ & $\begin{array}{r}0.0778 \\
0.1358 \\
0.0502 \\
0.0670 \\
0.7312 \\
0.0062 \\
0.1913 \\
-0.0194 \\
-0.0677 \\
-0.6263\end{array}$ & $\begin{array}{l}.2694 \\
.1617 \\
.2368 \\
.4926 \\
.2896 \\
.3429 \\
.1462 \\
.2625 \\
.2987 \\
.4043\end{array}$ \\
\hline
\end{tabular}

\subsection{Other variables}

This section discusses briefly about the data to construct the sample with the range from 1995 to 2012.

FDI data: We collect the data from country i to Vietnam at time $t$ from reputable and creditable sources such as Vietnam General Statistis Office (GSO) - Statistical Year Book, Ministry of Planning and Investment, ASEAN Statistical Year Book, Nguyen Thanh Xuan and Yuqing Xing (2006) and Pham Thi Hong Hanh (2011). ${ }^{12}$

Country characteristics: Yearly data for country i and Vietnam such as Gross Domestic Product (GDP), Infrastructure (measured by the telephone user ratio, Internet user ratio, number of airport departures), Inflation, Interest rate and Tax rate are provided by World Bank, while the Real Exchange rate is taken from Bruegel Exchange rate data of Darvas (2012).

Time-invariant data: Variables such as Distance (Dist $\left.{ }_{\mathrm{ivn}}\right)$ and Common Border $\left(\right.$ Contig $\left._{\text {ivn }}\right)$ are from the Institute for Research on International Economy (CEPII).

Crisis data: From the banking crisis of Laeven and Valencia (2012), the dummy Crisis $_{\text {it }}$ is constructed with the value of one from the year that country $i$ is affected by the banking crisis until it is not affected anymore. The value is equal to zero otherwise.

Openness data (WTO membership, Openness and ASEAN membership): Data for World Trade Organization (WTO) membership is constructed using the official information from WTO website. $\mathrm{WTO}_{\mathrm{it}}$ and $\mathrm{WTO}_{\mathrm{vnt}}$ are two dummies which are equal to one since the year of country i/Vietnam's becoming WTO member and zero otherwise. Yearly data for openness $\left(\right.$ Open $_{i t}$ and Open $\left._{\mathrm{vnt}}\right)$ is collected from the Penn World Table

\footnotetext{
${ }^{12}$ As the overlapping in the data from different sources appears, the priority will follow the above listed order.
} 
7.1. Information about ASEAN membership for Vietnam's partners $\left(\mathrm{ASEAN}_{\mathrm{it}}\right)$ is taken directly from the website of ASEAN Secretariat.

Institution data: Indexes for countries' institution such as Political Stability and Absence of Violence (Prspv $v_{i t}$ and Prspv $v_{v n t}$ ), Regulatory Quality (Prsrq ${ }_{i t}$ and Prsrq $q_{v n t}$ ), Control of Corruption (Prscc ${ }_{i t}$ and Prscc vnt $_{\text {) }}$, Voice and Accountability (Prsva ${ }_{i t}$ and Prsva $\left._{v n t}\right)$, Government Effectiveness (Prsge ${ }_{i t}$ and Prsge $\left.{ }_{v n t}\right)$ and Rule of Law (Prsrl ${ }_{i t}$ and Prsrl $_{v n t}$ ) are from World Bank, World Governance Indicators.

\section{Empirical strategies}

The gravity model is applied to consider the impact of heterogeneous BIT on FDI inflows to Vietnam. The main empirical specification for random effect model for panel data is as follows:

$$
\begin{gathered}
\operatorname{LogFDI}_{\text {ivnt }}=\alpha \text { BITindex }_{i v n t}+\beta_{1} \operatorname{Loggdp}_{i t}+\beta_{2} \text { Loggdp }_{\text {vnt }}+ \\
\beta_{3} \text { Logdist }_{i v n}+\beta_{4} \text { Contig }_{i v n}+\gamma_{j} W_{i v n t}+\phi_{t}+\epsilon_{i v n t}
\end{gathered}
$$

where $\mathrm{i}$ denotes country $\mathrm{i}$, vn denotes Vietnam, $\mathrm{t}$ is year $\mathrm{t}$.

* $\log F D I_{\text {ivnt }}$ is the FDI inflow from country i to Vietnam in year t;

* BITindex $_{i v n t}$ is a constructed index variable, denoting the value appointed to a BIT between country $\mathrm{i}$ and Vietnam at year $\mathrm{t}$;

* $\log G D P_{i t} / \log G D P_{v n t}$ denotes the log gross domestic product of country i/Vietnam in year $\mathrm{t}$;

* LogDist $_{i v n}$ is the log distance between country i and Vietnam;

* Contig $_{\text {ivn }}$ is a dummy variable with the value of 1 if country $i$ and Vietnam have common border and 0 otherwise;

* $\boldsymbol{\phi}_{\boldsymbol{t}}$ denotes time dummies ${ }^{13}$;

* $\mathbf{W}_{\text {ivnt }}$ is a vector including the following variables:

- Crisis $_{i t} /$ Crisis $_{\text {vnt }}$ is a dummy variable which is equal to one if country i/Vietnam is affected from a banking crisis in year $t$ and zero otherwise. ${ }^{14}$

\footnotetext{
${ }^{13}$ Including time dummies is necessary for the data. This is affirmed by the test results in Appendix 3, Table 11.

${ }^{14}$ Laeven and Valencia (2012) consider a country being affected by a banking crisis when two conditions are met. (i) There exist significantly negative changes in the banking system (such as loss, reduction in liability) and (ii) The government has important banking policy intervention in response to the above negative changes in the system. Based on these two conditions, Vietnam is only regarded by Laeven and Valencia (2012) to be affected by banking crisis in 1997, but not 2008.
} 
- $\boldsymbol{W t o}_{i t} / \boldsymbol{W T O}_{\boldsymbol{v} n t}$ is a dummy variable which is equal to 1 if country i/Vietnam is a GATT/WTO member in year $\mathrm{t}$ and 0 otherwise;

- Open $_{i t} / \mathbf{O p e n}_{\text {vnt }}$ denotes the openness of country i/Vietnam in year t;

- $\operatorname{Asean}_{\boldsymbol{i}}$ is a dummy variable which is equal to one if country $i$ is an ASEAN member;

- Inflation $_{\text {it }}$ /Inflation $_{\text {vnt }}$ is the inflation rate of county $\mathrm{i} / \mathrm{Vietnam}$ in year $\mathrm{t}$; Diffinflation $_{\text {ivnt }}$ is the difference in inflation between country i and Vietnam;

- Logexchangerate $_{i t} /$ Logexchangerate $_{\text {vnt }}$ is the natural logarithm of real exchange rate of the currency of country i/Vietnam against the US. Dollars in year $\mathrm{t}$ (2007 is the base year);

- Telephone $_{i t}$ Telephone $_{\text {vnt }}$ is the percentage of telephone users in country i/Vietnam in year t;

- Internet $_{i t}$ Internet $_{\text {vnt }}$ is the percentage of internet users in country $\mathrm{i} / \mathrm{Vietnam}$ in year t;

- Taxrate $_{\text {it }} /$ Taxrate $_{\text {vnt }}$ is the tax rate (of profit) in country i/Vietnam in year t;

- $\boldsymbol{P r s v a}_{i t} / \boldsymbol{P r s v a}_{\boldsymbol{v n t}}$ is the index of Voice and Accountability of country i/Vietnam in year t;

- $\boldsymbol{P r s g e}_{i t} / \boldsymbol{P r s g e}_{\boldsymbol{v n t}}$ is the index of Government Effectiveness of country i/Vietnam in year t;

- $\boldsymbol{P r s c c}_{i t} / \boldsymbol{P r s c c}_{\boldsymbol{v n t}}$ is the index of Control of Corruption of country i/Vietnam in year $\mathrm{t}$

- $\boldsymbol{P r s r q}_{i t} / \boldsymbol{P r s r q}_{\boldsymbol{v} n t}$ is the index of Regulatory Quality of country i/Vietnam in year t;

- $\boldsymbol{P r s p v _ { i t }} / \boldsymbol{P r s p}_{\boldsymbol{v} n t}$ is the index of Political Stability and Absence of Violence of country i/Vietnam in year t;

- $\boldsymbol{P r s r l}_{i l} / \mathbf{P r s r l}_{\boldsymbol{v} n t}$ is the index of Rule of Law of country i/Vietnam in year t.

The coefficient of interest in the previous equation is $\alpha$, which measures the effect of Vietnam's BIT signing on FDI inflows. If BIT does help Vietnam attract more FDI, this coefficient will be positive.

Table 4 presents the summary statistics of the main variables (See Appendix 3, Table 10 for information of further variables). Figure 3 shows the Kernel density estimate of BIT index in our whole sample across countries and across years. From this figure, we 
could see that besides the relatively high density of value of 0 (meaning no BIT between Vietnam and a country at a year), a high density of BIT index value ranges from 0.2 to 0.8 .

Table 4: Summary Statistics of Main Variables

\begin{tabular}{|c|c|c|c|c|c|}
\hline Variable | & Obs & Mean & Std. Dev. & Min & $\operatorname{Max}$ \\
\hline $\begin{array}{r}\text { logfdi_ivnt } \\
\text { bitindex_ivnt } \\
\text { loggdp_it } \\
\text { loggdp_vnt } \\
\text { logdist_ivn }\end{array}$ & $\begin{array}{l}557 \\
557 \\
557 \\
557 \\
557\end{array}$ & $\begin{array}{l}16.65226 \\
2725654 \\
26.12877 \\
24.84958 \\
8.448774\end{array}$ & $\begin{array}{l}2.692502 \\
.2406476 \\
2.244524 \\
.6155048 \\
.9046641\end{array}$ & $\begin{array}{r}9.21034 \\
0 \\
18.95542 \\
23.75514 \\
6.170767\end{array}$ & $\begin{array}{r}23.42926 \\
1 \\
30.41878 \\
25.77197 \\
9.780935\end{array}$ \\
\hline $\begin{array}{r}\text { contig_ivn } \\
\text { year_t } \\
\text { article1_ivnt } \\
\text { article2_ivnt } \\
\text { article3_ivnt }\end{array}$ & $\begin{array}{l}557 \\
557 \\
395 \\
395 \\
395\end{array}$ & $\begin{array}{l}.0933573 \\
2004.968 \\
1.237975 \\
9367089 \\
1.265823\end{array}$ & $\begin{array}{l}.291194 \\
4.936543 \\
.5953082 \\
.3242239 \\
.6068321\end{array}$ & $\begin{array}{r}0 \\
1995 \\
0 \\
0 \\
0\end{array}$ & $201 \frac{1}{2}$ \\
\hline $\begin{array}{l}\text { article4_ivnt } \\
\text { articles_ivnt } \\
\text { article6_ivnt } \\
\text { article7_-ivnt } \\
\text { article8_ivnt }\end{array}$ & $\begin{array}{l}395 \\
395 \\
395 \\
395 \\
395\end{array}$ & $\begin{array}{l}1.827848 \\
1.825316 \\
1.810127 \\
1.498734 \\
1.802532\end{array}$ & $\begin{array}{l}.5616638 \\
.5631376 \\
.5716649 \\
.650555 \\
.5757305\end{array}$ & $\begin{array}{l}0 \\
0 \\
0 \\
0 \\
0\end{array}$ & \\
\hline $\begin{array}{l}\text { article9_ivnt } \\
\text { article10_ivnt } \\
\text { article11-ivnt }\end{array}$ & $\begin{array}{l}395 \\
395 \\
395\end{array}$ & $\begin{array}{l}1.663291 \\
1.301266 \\
1.693671\end{array}$ & $\begin{array}{l}.6296759 \\
.619377 \\
.6209829\end{array}$ & $\begin{array}{l}0 \\
0 \\
0\end{array}$ & \\
\hline
\end{tabular}

Figure 3: Kernel density of BIT index in the whole sample

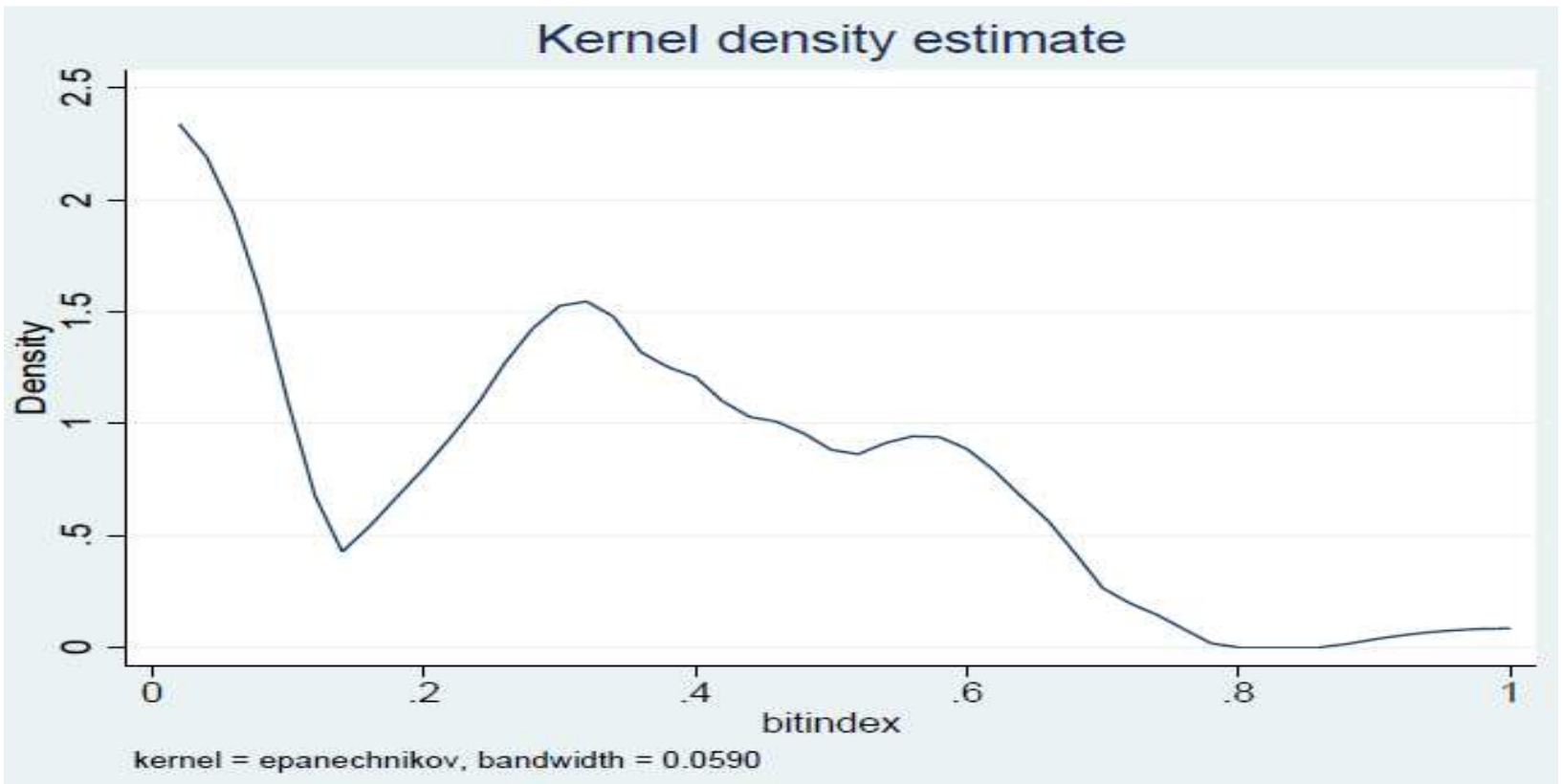

\section{Results}

The first results of the heterogenous BIT effect on FDI inflows to Vietnam are shown in Table 5. In all estimations, the identifier $I d$ in the bottom of the tables refers to the individual identifier $\mathrm{i}$-vn-t, for home country $\mathrm{i}$, host country Vietnam and year $\mathrm{t}$. The 
sample covers all 557 observations. The estimators for for two techniques of Fixed effect (FE) and Random effect (RE) for panel data are presented.

\subsection{Results for BIT index}

\subsubsection{Baseline results}

Baseline estimation results for the database of 557 observations are presented in this section. The basic variables are BIT index $\left(\right.$ BITindex $\left._{\text {ivnt }}\right)$, Gross Domestic Products $\left(\operatorname{Loggdp} p_{i t}\right.$ và Loggdp $\left.p_{v n t}\right)$, Distance between Vietnam and its partner - country i (Logdist $\left.{ }_{\mathrm{ivn}}\right)$ and Common Border dummies (Contig ivn $_{\text {). }}$.

Table 5 shows the estimation results applying two panel data techniques of Fixed effect - FE for the basic variables (Column (1), (3) and (5)) and Random effect - RE for the rests of Column (2), (4) and (6). We could see that there exist significant differences in coefficients of BIT index and Loggdp ${ }_{i t}$ with FE and RE. In addition, due to its own nature, RE-applying estimations show the coefficients of time-invariant variables such as Logdist and Contig. For the purpose of selecting the better technique, we carry out Hausman test. The result of this test (see Appendix 3, Table 12) supports RE technique (Also, based on the Breusch-Pagan Lagrange multiplier test, RE is preferable to OLS. See Appendix 3, Table 13 for the details). Hence, in the following sections of this paper, we will consider the RE-applying results for analysis.

The details for basic variables are as follows:

For BIT index $\left(\right.$ BITindex $_{\text {ivnt }}$ ), the results from Table 5 with RE techniques indicate that signing BIT does help Vietnam to raise its FDI inflows and more favorable BITs (with preferential articles) have higher positive impacts on FDI (at 1\% significant level). In particular, the increase in BIT index by 0.01 unit point leads to the rise of about 2.67\%-3.05\% ((Exp(1.3)-1) and $(\operatorname{Exp}(1.4)-1))$ in FDI flows into Vietnam (for the BIT index, coefficients are of about 1.3-1.4).

For $\operatorname{Loggdp}_{\mathrm{it}}$ and $\operatorname{Loggdp}_{\mathrm{vnt}}$ (presenting for Market size), results for Random effect in Table 5 illustrate that as GDP from Vietnam, as well as its partner increases by $1 \%$, Vietnam's FDI rises. However, the effect from the change in Vietnam's GDP is stronger than that in its partner's. As Vietnam's GDP rises by $1 \%$, FDI into Vietnam boosts by 0.3 to $0.8 \%$. As country i's GDP rises by $1 \%$, FDI just goes up by 0.2 to $0.3 \%$. 
These positive impacts are consistent with what are expected from gravity model. ${ }^{15}$ As the market size of host country (like Vietnam) gets larger, more opportunities for sales and profits for enterprises will appear. That will attract investors, especially marketseeking ones.

Table 5: Baseline results for FDI

\begin{tabular}{|c|c|c|c|c|c|c|}
\hline & \multicolumn{6}{|c|}{$\operatorname{LogFDI}_{\text {ivnt }}$} \\
\hline & (1) & (2) & (3) & (4) & (5) & (6) \\
\hline \multirow[t]{2}{*}{ BITindex $_{\text {ivnt }}$} & 0.582 & $1.367 * * *$ & 0.852 & $1.379 * *$ & 0.844 & $1.421 * * *$ \\
\hline & $(0.459)$ & $(0.515)$ & $(0.616)$ & $(0.543)$ & $(0.615)$ & $(0.542)$ \\
\hline \multirow[t]{2}{*}{$\log g d p_{i t}$} & 0.225 & $0.275 * *$ & 0.464 & $0.298 * * *$ & 0.364 & $0.283 * * *$ \\
\hline & $(0.464)$ & $(0.137)$ & $(0.389)$ & $(0.0959)$ & $(0.392)$ & $(0.0943)$ \\
\hline \multirow[t]{2}{*}{$\operatorname{Loggdp_{vnt}}$} & $0.580 * *$ & $0.307^{*}$ & $0.937 * * *$ & $0.893 * * *$ & $1.003^{* * *} *$ & $0.894 * * *$ \\
\hline & $(0.268)$ & $(0.174)$ & $(0.305)$ & $(0.149)$ & $(0.307)$ & $(0.149)$ \\
\hline \multirow[t]{2}{*}{ Logdistant $_{i v n}$} & & $-0.785 * *$ & & $-0.701 * *$ & & $-0.708 * *$ \\
\hline & & $(0.368)$ & & $(0.327)$ & & $(0.319)$ \\
\hline \multirow[t]{2}{*}{ Contig $_{i v n}$} & & -1.463 & & -1.196 & & -1.199 \\
\hline & & $(1.255)$ & & $(1.217)$ & & $(1.185)$ \\
\hline$O b$. & 557 & 557 & 555 & 555 & 555 & 555 \\
\hline Rsquared & 0.752 & & 0.735 & & 0.737 & \\
\hline No.Id & 71 & 71 & 70 & 70 & 70 & 70 \\
\hline Type & FE & $\mathrm{RE}$ & $\mathrm{FE}$ & $\mathrm{RE}$ & $\mathrm{FE}$ & $\mathrm{RE}$ \\
\hline Timedummies & Yes & Yes & No & No & No & No \\
\hline Crisises & No & No & Yes & Yes & Yes & Yes \\
\hline
\end{tabular}

(Dependent variable is Natural logarithm of FDI from country i to Vietnam at year t. The panel techniques of Fixed effect and Random effect are applied. Id denotes country i - Vietnam. $* * * / * * / *$ present significant level of $\mathrm{t}$-statistics at $1 \% / 5 \% / 10 \%$ level.)

The sign, magnitude and significance level of Distance $\left(\right.$ Logdist $_{\mathrm{iv}}$ ) indicate the negative effect of the change in distance between Vietnam and its partner on FDI inflows to Vietnam. If distance goes up by $1 \%$, FDI reduces by $0.7-0.8 \%$. This negative impact of distance is also consistent with gravity model. The increase in distance reflects the rise in transportation cost, discouraging investors in their investment activities. However, despite the above significant consistency of distance, the other variable representing for transportation cost such as common border (Contig) has no significant influence on FDI into Vietnam. This could be explained by the fact that not many partners included in the sample share common borders with Vietnam.

\footnotetext{
${ }^{15}$ The positive impact of market size - proxied by loggdp on FDI for panel data is strongly supported by Asiedu (2006), Mohammed and Sidiropoulos (2010), Vijayakumar et. al. (2010) and Botrić and Škuflić (2006).
} 


\subsubsection{Openness with crisises, WTO, ASEAN membership}

As mentioned in the literature review, one of the mechanisms that BIT could have an impact on FDI inflows is that BIT signing of a country gives investors signals for the country's openness with more favorable conditions (signaling effects). Hence, we want to see how will the effect of BIT on FDI inflows change as other open activities of Vietnam and its partners are considered. Those activities include crisises, World Trade Organization (WTO) membership and ASEAN membership.

Regarding crisises and economic shocks, these are proxied by Crisis variables (Crisis $_{\text {it và Crisis }}$ vnt $_{\text {) }}$ and time dummies. As controlling for these effects (Columns (2-6) in the baseline result table 6), it is clear that in RE equations, BIT index does have significantly positive impacts on FDI. For its own effect, the impact of crisis on FDI in Table 6 is entirely different from expectation. While crisises from country $i$ has no considerable impact, the banking crisis in 1997 leads to the rise in FDI to Vietnam. This impact is proved not only by positive coefficients of Crisis vnt $_{\text {, }}$ but also affirmed by the coefficient of time dummies_It_1997. This effect disappears in later years of 1998, 1999. The impact of 1997 banking crisis in Vietnam on FDI could be explained that the private capital flows heavily affected by the banking crisis is mainly short-term one such as Foreign Portfolio Investment (FPI), rather than such a long-term as FDI. During this time, Vietnam almost attracts and receives private flows under the category of FDI, hence, the negative impact on FDI to Vietnam doesn't significantly exist. In addition, due to being less negatively affected by the crisis, Vietnam even receives more FDI from investors who shift from other Asian heavily-affected countries. This is supported by the fact that FDI into Vietnam in 1997 is mainly from Asian countries (Thailand, Singapore, Indonesia...). However, after that year, the spread out of negative influence of the world financial crisis does make investors hesitate in investing into Asian market in general and Vietnam in particular.

Regarding the crisis in 2008, according to Laeven and Valencia (2012), Vietnam is not regarded to be affected by this crisis due to not meeting two conditions for important banking crisis. Therefore, the impact of 2008 crisis is only taken into consideration from the perspectives of Vietnam's partners, but not Vietnam itself. However, to make clearer the possible effect of this crisis, the authors also control for the dummy variable of the crisis 2008 for Vietnam $\left(t 2008_{\mathrm{vn}}\right)$ and its 1 and 2 year-delay 
$\left({\text { Lead1t } 2008_{v n} \text { and Lead2t2008 }}_{v n}\right)$. The results in Table 6, Columns (2)-(6) show positive impacts of these variables on FDI into Vietnam. They are also supported by dummies of _It_2008,_It_2009 and_It_2010 as well.

Table 6: Results for Crisises and Time shocks

\begin{tabular}{|c|c|c|c|c|c|c|}
\hline & \multicolumn{6}{|c|}{$\log F D I_{i v n t}$} \\
\hline & (1) & (2) & (3) & (4) & (5) & (6) \\
\hline \multirow[t]{2}{*}{ _It_1997 } & $0.327 * *$ & $0.382 * * *$ & & & & \\
\hline & $(0.147)$ & $(0.135)$ & & & & \\
\hline \multirow[t]{2}{*}{ _It_1998 } & $-0.470 * *$ & $-0.405^{*}$ & & & & \\
\hline & $(0.209)$ & $(0.218)$ & & & & \\
\hline \multirow[t]{2}{*}{ _It_1999 } & $-0.870 * * *$ & $-0.816^{* * *}$ & & & & \\
\hline & $(0.244)$ & $(0.260)$ & & & & \\
\hline \multirow[t]{2}{*}{ It_2006 } & $0.634 *$ & $0.837 * *$ & & & & \\
\hline & $(0.352)$ & $(0.356)$ & & & & \\
\hline \multirow[t]{2}{*}{ _It_2007 } & $1.033 * * *$ & $1.206^{* * * *}$ & & & & \\
\hline & $(0.268)$ & $(0.265)$ & & & & \\
\hline \multirow[t]{2}{*}{ _It_2008 } & $0.868^{* *}$ & $0.941 * *$ & & & & \\
\hline & $(0.434)$ & $(0.434)$ & & & & \\
\hline \multirow[t]{2}{*}{ _It_2009 } & 0.503 & $0.649^{*}$ & & & & \\
\hline & $(0.355)$ & $(0.362)$ & & & & \\
\hline \multirow[t]{2}{*}{ It_2010 } & $1.290 * * *$ & $1.611^{* * *}$ & & & & \\
\hline & $(0.402)$ & $(0.397)$ & & & & \\
\hline \multirow[t]{2}{*}{ _It_2011 } & 0.362 & 0.442 & & & & \\
\hline & $(0.315)$ & $(0.322)$ & & & & \\
\hline \multirow[t]{2}{*}{ Crisis $_{i t}$} & & & 0.169 & 0.163 & -0.0795 & -0.0725 \\
\hline & & & $(0.213)$ & $(0.207)$ & $(0.261)$ & $(0.256)$ \\
\hline \multirow[t]{2}{*}{ Crisis $_{v n t}$} & & & 0.738* & $0.753 *$ & 0.673* & 0.673* \\
\hline & & & $(0.389)$ & $(0.399)$ & $(0.390)$ & $(0.403)$ \\
\hline \multirow[t]{2}{*}{ Crisis $_{v n(t+1)}$} & & & 0.248 & 0.258 & 0.109 & 0.0932 \\
\hline & & & $(0.388)$ & $(0.398)$ & $(0.395)$ & $(0.409)$ \\
\hline \multirow[t]{2}{*}{ Crisis $_{v n(t+2)}$} & & & 0.607 & 0.622 & 0.596 & 0.569 \\
\hline & & & $(0.397)$ & $(0.402)$ & $(0.404)$ & $(0.411)$ \\
\hline \multirow[t]{2}{*}{$t 2008$} & & & $\mathbf{0 . 6 3 6} * *$ & $0.617 * *$ & $0.582 * *$ & $\mathbf{0 . 5 5 0} * *$ \\
\hline & & & $(0.259)$ & $(0.260)$ & $(0.260)$ & $(0.263)$ \\
\hline \multirow[t]{2}{*}{ Lead1t $2008_{v n}$} & & & $0.889 * * *$ & $0.940 * * *$ & $0.759 * * *$ & $0.799 * * *$ \\
\hline & & & $(0.252)$ & $(0.258)$ & $(0.261)$ & $(0.270)$ \\
\hline \multirow[t]{2}{*}{ Lead2t2008 } & & & $0.658 * * *$ & $0.668 * * *$ & $0.600^{* *}$ & $0.594^{* *}$ \\
\hline & & & $(0.254)$ & $(0.259)$ & $(0.264)$ & $(0.270)$ \\
\hline \multirow[t]{2}{*}{ Crisis $_{i(t+1)}$} & & & & & 0.327 & 0.291 \\
\hline & & & & & $(0.289)$ & $(0.300)$ \\
\hline \multirow[t]{2}{*}{ Crisis $_{i(t+2)}$} & & & & & 0.140 & 0.200 \\
\hline & & & & & $(0.243)$ & $(0.252)$ \\
\hline$O b$. & 557 & 557 & 555 & 555 & 555 & 555 \\
\hline Rsquared & 0.752 & & 0.735 & & 0.737 & \\
\hline No. Id & 71 & 71 & 70 & 70 & 70 & 70 \\
\hline Type & FE & $\mathrm{RE}$ & FE & $\mathrm{RE}$ & FE & $\mathrm{RE}$ \\
\hline Timedummies & Yes & Yes & No & No & No & No \\
\hline Crisises & No & No & Yes & Yes & Yes & Yes \\
\hline
\end{tabular}

(Dependent variable is Natural logarithm of FDI from country i to Vietnam at year t. The panel technique of Random effect is applied. Id denotes country $\mathrm{i}$ - vietnam. $* * * / * * / *$ present significant level of $\mathrm{t}$ statistics at $1 \% / 5 \% / 10 \%$ level. BITindex ${ }_{\text {ivnt }}, \operatorname{Loggdp}_{\mathrm{i}}$, Loggdp $_{\mathrm{vn}}$, Logdist $_{\mathrm{ivn}}$, Contig $_{\text {ivn }}$ are controlled for) 
Regarding WTO membership, openess in general and ASEAN membership, Table 7 indicates the fact that the positive effects of BIT don't change given these variable controlled. The magnitude of BITindex variable is much higher than other variables. At first, we could see from Column (1) is that WTO membership also helps to attract more FDI into the country. Meanwhile, the impact of BIT is even double than that of Vietnam's WTO membership. The explanation could be made is that while BIT with promotion and protection conditions directly covering investors' activities, WTO (despite its investment-related articles) focuses mainly on trade, leading to its smaller effect on FDI inflows to Vietnam. This effect of WTO is further supported by the time dummy of _It_2007 in the above Table 6 .

Table 7: Results for FDI controlling for Openness

\begin{tabular}{|l|c|c|c|}
\hline & \multicolumn{3}{|c|}{ LogFDIivnt } \\
\hline & $(1)$ & $(2)$ & $(3)$ \\
\hline BITindex $_{\text {ivnt }}$ & $\mathbf{1 . 4 1 9}^{* * *}$ & $\mathbf{1 . 0 6 6}^{* *}$ & $\mathbf{1 . 3 4 5}^{* *}$ \\
\hline & $(0.439)$ & $(0.490)$ & $(0.508)$ \\
\hline Loggdp $_{\text {it }}$ & $0.292^{* *}$ & $0.303^{*}$ & $0.291^{* *}$ \\
\hline & $(0.135)$ & $(0.159)$ & $(0.141)$ \\
\hline Loggdp $_{\text {vnt }}$ & $0.454^{*}$ & -1.946 & $0.304^{*}$ \\
\hline & $(0.272)$ & $(1.345)$ & $(0.174)$ \\
\hline Logdistant $_{\text {ivn }}$ & $-0.736^{*}$ & $-0.567^{*}$ & -0.519 \\
\hline & $(0.388)$ & $(0.318)$ & $(0.555)$ \\
\hline Contig $_{\text {ivn }}$ & -1.064 & -1.301 & -1.519 \\
\hline & $(1.384)$ & $(1.210)$ & $(1.413)$ \\
\hline WTOit & 0.338 & & \\
\hline & $(0.665)$ & & \\
\hline WTOvnt & $\mathbf{0 . 6 1 1 * *}$ & & \\
\hline & $(0.267)$ & & \\
\hline Openit & & $\mathbf{0 . 0 0 5 1 4} *$ & \\
\hline & & $(0.00289)$ & \\
\hline Openvnt & & $\mathbf{0 . 0 5 8 1 * *}$ & \\
\hline & & $(0.0280)$ & \\
\hline ASEANit & & & 0.978 \\
\hline & & & $(1.112)$ \\
\hline Ob. & 557 & 458 & 557 \\
\hline No. Id & 71 & 62 & 71 \\
\hline Timedummies & No & Yes & Yes \\
\hline Natural & & & \\
\hline
\end{tabular}

(Dependent variable is Natural logarithm of FDI from country i to Vietnam at year t. The panel technique of Random effect is applied. Id denotes country i - vietnam. $* * * * * * * *$ present significant level of $\mathrm{t}$-statistics at $1 \% / 5 \% / 10 \%$ level.)

Secondly, as looking at Openness in general, it is clearly indicated that like WTO's membership, openness does have positive effects on FDI (this affirms further the importance of market openness of a country to investors) but the magnitude is even much 
smaller than WTO membership and BIT. This proves further for the necessity of direct inclusion of investment-related regulations.

In contrast to WTO membership and Openness, ASEAN membership of Vietnam's partner (country i) has no significant effect on FDI. This could be explained by the fact that FDI from ASEAN countries is not as high as from outside-ASEAN countries.

\subsubsection{Macroeconomic, Infrastructure and Institutional factors}

Besides the case of controlling for openness, as other variables of macroeconomic, infrastructure and institution ones are considered, it could be seen from Appendix 3, Table 15-17 that the effects of BIT index and main variables of gravity model (Loggdp, Logdist) are still consistent. These results support further the real positive impact of BIT on FDI.

Regarding macroeconomic factors, from Appendix 3, Table 15, it's quite surprising that the impacts are out of expectation. All most all proxies for macroeconomic situation of both Vietnam and its partners (Inflation ${ }_{i \text {, }}$ Inflation $_{\text {vnt }}$,

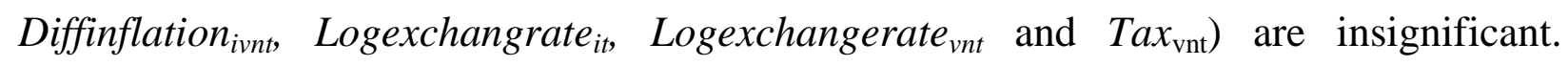
However, if we look into the variable of Loggdp, especially for Vietnam, we could find out that the magnitudes of these are much higher than those in the cases without controlling for mentioned macroeconomic factors. Hence we could think that the fast growth of Vietnamese market during the consideration period captures all effects from macroeconomic perspectives.

About infrastructure, in our points of view, this is an important determinant reflecting host countries' supports for investors to reduce their costs and increase the possibility of receiving information. We use two different proxies for infrastructure, including Telephone User Ratio $\left(\right.$ Telephone $_{i t}$, Telephone ${ }_{\mathrm{vnt}}$ ), Internet User Ratio (Internet $_{\mathrm{it}}$, Internet $\mathrm{vnt}_{\mathrm{v}}$ ) to see the consistency of the impact of infrastructure on FDI. According to Appendix 3, Table 16, two proxies of Telephone User Ratio for both Vietnam and country $\mathrm{i}$ have a positive impact on FDI into Vietnam and that effect for Vietnam is higher than that of country $i$ (see Columns (1)). It could be interpreted that as telephone user ratio increases by $1 \%$ in country i/Vietnam, FDI will go up correspondently by $0.0258 \% / 0.0856 \%$. For Internet user ratio, the effect is quite clear 
for Vietnam's partner. For Vietnam, despite being statistically insignificant, the positive impact is also captured. These effects are consistent with what are expected. ${ }^{16}$ They could be explained that the rise in telephone and internet user ratio make it easier for investors to do their transactions, reducing their transaction cost and encouraging them to invest more.

For looking deeply inside the institutional quality which is more and more important for investors, we indifferent proxies for institution such as: Political Stability and Absence of Violence $\left(\operatorname{Prspv}_{\mathrm{it}}, \operatorname{Prspv}_{\mathrm{vnt}}\right)$, Regulatory Quality $\left(\operatorname{Prsrq}_{\mathrm{it}}, \operatorname{Prsrq}_{\mathrm{vnt}}\right)$, Control of Corruption (Prscc $\left.\mathrm{i}_{\mathrm{i}}, \operatorname{Prscc}_{\mathrm{vnt}}\right)$, Voice and Accountability (Prsva $\left.\mathrm{i}_{\mathrm{it}}, \operatorname{Prsva}_{\mathrm{vnt}}\right)$, Government Effectiveness $\left(\operatorname{Prsge}_{\mathrm{it}}, \operatorname{Prsge}_{\mathrm{vnt}}\right)$ and Rule of Law $\left(\operatorname{Prsrl}_{\mathrm{it}}, \operatorname{Prsrl}_{\mathrm{vnt}}\right)$. In Appendix 3, Table 17, it is clear that out of six proxies for institution, three of Vietnam, including Political Stability and Absence of Violence, Regulatory Quality and Control of Corruption have considerable effects on FDI (The coefficients have corresponding values of $10.75 ; 3.186$ and 1.498) (much higher than that of country i), especially Political Stability and Absence of Violence. These influences actually reflect the fact that in addition to the two factors of role of regulatory quality and control of corruption, political stability is a key element for attracting FDI of Vietnam. Besides, from Columns (2), (4), (6), as these 3 proxies are controlled for, the coefficients for BIT index get a little higher.

\subsubsection{New vs. Old BITs}

To make clear the impact of heterogeneous BITs on FDI, besides considering the whole sample including partners with and without BITs with Vietnam during the period of 1995-2012, we do look at different samples of (i) partners having BITs (called all members), (ii) partners having BITs with Vietnam during 1995-2012 (called new members) and (iii) partners having BITs with Vietnam before the period of 1995-2012 (called old members). Estimators for these 3 samples for baseline equations with RE techniques are shown in the below table 8.

For all of these 3 samples, the signs and magnitudes for BIT index's coefficients prove for the significantly positive effect of heterogeneous BIT on FDI. At first, regarding all members sample with 36 partners (see Appendix 3, Table 14 for the list of

\footnotetext{
${ }^{16}$ The positive effect is consistent with the what has been found by Asiedu (2006), Biswas (2002), Mhlange et. al. (2010).
} 
countries), the value of BIT index coefficient is 1.446 , which is higher than that for whole sample, showing that signing BITs with countries do help Vietnam to increase its FDI inflows (In this sample, all partners with no BITs with Vietnam are excluded). Secondly, for new members sample, the interested coefficient for BIT index is even higher than that for all members sample. The BIT index ranges from 0 (not signing BIT yet) to 1 . Hence, the coefficient for this sample captures not only within-country effect of entering BITs, but also across-country effect of heterogeneous BITs. The impact for this new members sample could be even higher if the sample doesn't cover such a small number of partners (only 9 countries), 2 of which are quite small such as Lao and Cambodia.

Table 8: Results for FDI in All, New and Old members samples

\begin{tabular}{|l|c|c|c|}
\hline & All members & New members & Old members \\
\hline & $(1)$ & $(2)$ & $(3)$ \\
\hline BITindex $_{\text {ivnt }}$ & $\mathbf{1 . 4 4 6}_{* * *}^{*}$ & $\mathbf{2 . 3 5 1}^{* * *}$ & $\mathbf{4 . 1 5 5}^{*}$ \\
\hline & $(0.456)$ & $(0.777)$ & $(2.218)$ \\
\hline Loggdp $_{\text {it }}$ & $0.788^{* * *}$ & $1.132^{* *}$ & $0.754^{* * *}$ \\
\hline & $(0.167)$ & $(0.522)$ & $(0.266)$ \\
\hline Loggdp $_{\text {vnt }}$ & 0.0208 & -0.545 & 0.0566 \\
\hline & $(0.201)$ & $(0.591)$ & $(0.257)$ \\
\hline Logdistant $_{\text {ivn }}$ & $-1.555^{* * *}$ & -0.698 & $-1.659^{* * *}$ \\
\hline & $(0.480)$ & $(1.017)$ & $(0.569)$ \\
\hline Contig $_{\text {ivn }}$ & $-1.741^{*}$ & 1.994 & -1.382 \\
\hline & $(0.912)$ & $(3.882)$ & $(0.855)$ \\
\hline Ob. & 394 & 99 & 295 \\
\hline No. Id & 36 & 9 & 27 \\
\hline Timedummies & Yes & Yes & Yes \\
\hline
\end{tabular}

(Dependent variable is Natural logarithm of FDI from country i to Vietnam at year t. The panel technique of Random effect is applied. Id denotes country i - vietnam. $* * * / * * / *$ present significant level of t-statistics at $1 \% / 5 \% / 10 \%$ level.)

Finally, for old members sample covering 27 countries, the values of BIT index are higher than 0 for all observations during the consideration period, hence, the coefficient entirely captures the heterogeneous BIT impact on FDI. This result is very important and it is difficult to achieve if the dummy variable with two value of 0,1 for BIT, rather than BIT index is applied here. We could realize that the value of the coefficient for this sample is much higher than that for all members and new members samples. In our point of view, these results support commitment effect through which investors in countries having BITs with Vietnam believe in the implementation of favorable articles by Vietnamese Government, hence, they will carry out further FDI 
activities. In addition, the above findings affirm further about the essence of looking at contents of various BITs and difference in favorable articles is very necessary for attracting FDI into Vietnam.

\subsection{Articles of BIT}

Table 9: Results for FDI with particular articles

\begin{tabular}{|c|c|c|c|c|c|c|c|c|c|c|c|}
\hline & \multicolumn{11}{|c|}{ LogFDIivnt } \\
\hline & (1) & (2) & (3) & (4) & (5) & (6) & (7) & (8) & (9) & (10) & (11) \\
\hline \multirow[t]{2}{*}{ Articlel } & $0.437 * *$ & & & & & & & & & & \\
\hline & $(0.215)$ & & & & & & & & & & \\
\hline \multirow{2}{*}{ Article2 } & & $0.465 *$ & & & & & & & & & \\
\hline & & $(0.257)$ & & & & & & & & & \\
\hline \multirow[t]{2}{*}{ Article3 } & & & $0.383 * *$ & & & & & & & & \\
\hline & & & $(0.194)$ & & & & & & & & \\
\hline \multirow[t]{2}{*}{ Article4 } & & & & 0.237 & & & & & & & \\
\hline & & & & $(0.184)$ & & & & & & & \\
\hline \multirow[t]{2}{*}{ Article5 } & & & & & 0.242 & & & & & & \\
\hline & & & & & $(0.186)$ & & & & & & \\
\hline \multirow[t]{2}{*}{ Article6 } & & & & & & 0.232 & & & & & \\
\hline & & & & & & $(0.187)$ & & & & & \\
\hline \multirow[t]{2}{*}{ Article7 } & & & & & & & 0.311 & & & & \\
\hline & & & & & & & $(0.217)$ & & & & \\
\hline \multirow[t]{2}{*}{ Articles } & & & & & & & & 0.194 & & & \\
\hline & & & & & & & & $(0.202)$ & & & \\
\hline \multirow[t]{2}{*}{ Article 9} & & & & & & & & & 0.199 & & \\
\hline & & & & & & & & & $(0.187)$ & & \\
\hline \multirow[t]{2}{*}{ Article10 } & & & & & & & & & & 0.369 & \\
\hline & & & & & & & & & & $(0.249)$ & \\
\hline \multirow[t]{2}{*}{ Article11 } & & & & & & & & & & & 0.292 \\
\hline & & & & & & & & & & & $(0.202)$ \\
\hline$O b$. & 557 & 557 & 557 & 557 & 557 & 557 & 557 & 557 & 557 & 557 & 557 \\
\hline No. Id & 71 & 71 & 71 & 71 & 71 & 71 & 71 & 71 & 71 & 71 & 71 \\
\hline Timedummies & Yes & Yes & Yes & Yes & Yes & Yes & Yes & Yes & Yes & Yes & Yes \\
\hline
\end{tabular}

(Dependent variable is Log of FDI from country i to Vietnam at year t. The panel technique of RE is applied. Id denotes country i - vietnam. $* * * * * / *$ present significant level of $\mathrm{t}$-statistics at $1 \% / 5 \% / 10 \%$ level. BITindex ${ }_{\text {ivnt }}, \operatorname{Loggdp}_{\mathrm{it}}, \operatorname{Loggdp}_{\mathrm{vnt}}$, Logdist $_{\mathrm{ivn}}$, Contig $_{\mathrm{ivn}}$ are controlled for.)

Despite being considered in different ways, articles are quoted from being less to more favorable. Hence, we find that it is unnecessary to divide articles into 3 groups as initial targets. ${ }^{17}$ Rather than that, we look at the effect of each article on FDI. As presented in Table 9, while all articles have positive effects on FDI, only 3 of them are

\footnotetext{
${ }^{17}$ The 3 groups which we intend to divide initially are (i) Group of provisions mentioning the broad range such as Definition of Investment, Temporal scope of Application... (narrow vs. broad), (ii) Group about the existence of provisions (if these are provided in BITs or not) favoring investors such as National Treatment, Most Favored Nations..., and (iii) For the group about existence of provisions which are barriers for investors, such as Non-economic Standards..
} 
significant with relatively high magnitudes $(0.437 ; 0.465$ and 0.383 respectively). These 3 articles include Definition of Investment, Admission vs. Establishment and National Treatment. We could say that the broadening the Definition of Investment, broadening further Admission to Establishment and including National Treatment in BITs do help Vietnam to increase its FDI attraction.

\section{Conclusion}

Taking advantage of a wide range of data from 1995 to 2012 and random effect technique of panel data, the positive effect of heterogeneous BIT on FDI inflows to Vietnam, which was in doubt, has been confirmed by the paper. It means signing BIT does help Vietnam to attract more FDI and more favorable BITs lead to further FDI inflows into the country. These results are not only supported by the whole sample but also all, new and old members. Hence, we could say that commitment effect is a very important channel in explaining the influence of BITs. In addition to such commitment effect, signaling effect to the openness of Vietnam for investors is also essential to consider. This is proved as BITs are simultaneously with other variables indicating Vietnam's openness.

Besides the above general effect, as considering the separate impact of each in our 11 main articles, we find out that broadening Definition of Investment, broadening by moving from Admission to Establishment and including National Treatment in BITs give more impetus for investors to carry out FDI investment in Vietnam.

In addition, our results also show the role of Political Stability and Absence of Violence, Regulatory Quality and Control of Corruption as essential factors of attracting FDI.

From those above results, for further taking advantage of BITs to attract more FDI, We do suggest that Vietnam should review and make necessary adjustments for signed BITs' articles. Moreover, the country should also take further consideration in favorable articles for future BITs, especially 3 articles of Definition of Investment, Admission vs. Establishment and National Treatment. In addition to these, it is also necessary for Vietnam to maintain its political stability, improve the regulatory quality and implement further control of corruption. 


\section{REFERENCE}

- Aisbett, E. K. (2009), Bilateral Investment Treaties and Foreign Direct Investment: Correlation versus Causation (in: Karl P. Sauvant; Lisa E. Sachs, The Effect of Treaties on Foreign Direct Investment), Oxford: Oxford University Press, 395-435.

- Allee, T. and Peinhardt, C. (2011), Contingent Credibility: The Impact of Investment Treaty Violations on Foreign Direct Investment, International Organization, 65, 401-432.

- Asiedu, E. (2006), Foreign Direct Investment in Africa: The Role of Natural Resources, Market Size, Government Policy, Institutions and Political Instability, University of Kansas.

- Bellak, C. (2013), How Bilateral Investment Treaties Impact on Foreign Direct Investment: A Meta-analysis of Public Policy, Version for 2013 MAER Network Colloquium.

- Bellak, C. and Chaisse, J. (2011), Do Bilateral Investment Treaties Promote Foreign Direct Investment? Preliminary Reflections on a New Methodology, Transnational Corporations Review, Vol. 3.

- Berger, A. et. al. (2010), Do Trade and Investment Agreements Lead to More FDI? Accounting for Key Provisions Inside the Black Box, Kiel Institute, Working Papers, Issue 1647, 1-28.

- Botrić, V. and Škuflić, L. (2006), Main Determinants of Foreign Direct Investment in the South east European Countries, Transition Studies Review, Vol 13, 359-377.

- Busse, M. et. al. (2010), FDI Promotion through Bilateral Investment Treaties: More Than a Bit? Review of World Economics 146 (1).

- Cao, V. (2013), Does World Trade Organization Membership account for the Increase in FDI inflows to Vietnam? What about other factors, External Economics Review - Foreign Trade University, 58.

- Chaisse, Julien (2013) Exploring the Confines of International Investment and Domestic Health Protections - General exceptions clause as a forced perspective (2013) 39(2/3) American Journal of Law \& Medicine 332-361 
- Chaisse, Julien (2013) Assessing the Exposure of Asian States to Investment Claims (2013) 6(2) Contemporary Asia Arbitration Journal 187-225

- Chaisse, Julien (2014) The Investment Version of Asian Noodle Bowl-Proliferation of International Investment Agreements, Asian Development Bank Working Paper No.128, May 2014 (75 p.)

- Darvas, Z., 2012, Real Effective Exchange Rates for 178 Countries: A New Database, Bruegel working paper.

- Egger, P. and Pfaffermayr, M. (2004), The Impact of Bilateral Investment Treaties on Foreign Direct Investment, Journal of Comparative Economics, Elsevier. Vol. 32(4) December.

- Elkins, Z. et al. (2006), Competing for Capital: the Diffusion of Bilateral Investment Treaties, 1960-2000, International Organization 60(4), 811-846.

- General Statistics Office, Yearly Statistical Year Book 2000-2012 (except 2002)

- Guerin, S. (2011), Law and Foreign Direct Investment, Institute for European Studies Working Paper No. 4/2011.

- Hallward-Driemeier, M. (2003), Do Bilateral Investment Treaties attract Foreign Direct Investment? Only a bit... and they could bite, World Bank Policy Research Working Paper 3121,. Washington, DC: The World Bank.

- Jandhyala, S. and Weiner, R. (2012), Do International Investment Agreements Protect Investment? Petroleum Evidence, mimeo.

- Jang, K. (2011), The Effect of Heterogeneous BITs on FDI Inflows: The Case of Developing Asian Countries, Korea University.

- Kerner (2009), Why should I believe you? The Costs and Consequences of Bilateral Investment Treaties, International Studies Quarterly 53(1), 73-102.

- Mohammed, S. E. and Sidiropoulos, M. G. (2010), Another Look at the Determinants of Foreign Direct Investment in MENA countries: An Empirical Investigation, Journal of Economic Development, 35(2), 75-95.

- Neumayer, E. and L. Spess (2005), Do Bilateral Investment Treaties Increase Foreign Direct Investment to Developing Countries? World Development 33 (10). 
- Pham, T. H. H, 2011, Does the WTO accession matter for the Dynamics of Foreign Direct Investment and Trade? Vietnam's new evidence, University of Rouen

- Salacuse, J. W., \& Sullivan, N. P. (2005), Do BITs Really Work? An Evaluation of Bilateral Investment Treaties and Their Grand Bargain, Harvard International Law Journal, 46(1).

- Swenson, D. L. (2005), Why do Developing countries Sign BITs?, U.C. Davis Journal of International Law and Policy, 12(1), 131-155.

- Tobin, J. and Rose-Ackerman, S. (2005), Foreign Direct Investment and the Business Environment in Developing Countries: The Impact of Bilateral Investment Treaties, Yale Law School Center for Law, Economics, and Public Policy Research Paper No. 293.

- Tobin, J. and Rose-Ackerman, S. (2011), "When BITs have some bite: The political-economic environment for bilateral investment treaties," The Review of International Organizations, Springer, vol. 6(1), pages 1-32, March.

- UNCTAD (2003), World Investment Report 2003.

- UNCTAD (2009), World Investment Report 2009

- UNCTAD (2012), World Investment Report 2012.

- Vandevelde, K. (1998), The Political Economy of a Bilateral Investment Treaty, The American Journal of International Law, 92 (4), 621-641

- Vijayakumar, N. et. al. (2010), Determinants of FDI in BRICS countries: A panel analysis, International Journal of Business Science and Applied Management, 5 (3), 1-13.

- Xuan N.T., Xing Y., 2008, Foreign direct investment and exports The experiences of Vietnam, Economics of Transition, Volume 16

- Wälde, K. (2005), Endogenous Growth Cycles, International Economic Review, 46: $867-894$ 


\section{APPENDIX}

\section{APPENDIX 1: CODING ARTICLES IN BIT INDEX}

In this paper, we provide preliminary insights on the "BITSEL index" which is based on the 11 most important elements found in most of the existing BITs as presented in table 2. Each of them is reviewed below following a standard methodology: What is the criterion? How can it be legally defined? What are the examples in existing treaties? $^{18}$

\section{Definition of Investment: narrow $=1$, broad $=2$}

The subject-matter of the investment agreement is determined by the definition of the term "investment" together with that of the "investor". The concept of investment governs the assets that fall under the scope of application of the agreement. In other words, it answers the question of what type of investments are covered. Traditionally aimed at investment protection, most BITs define "investment" in a broad and openended manner covering not only the capital that has crossed borders but also practically all other kinds of assets of an investor in the territory of the host country. However, a detailed observation shows that among BITs one can distinguish several kinds of definitions. Firstly, there is the traditional "asset-based" definition, which, with several variations, has continued to be the most common approach. Secondly, another definition, the use of which has diminished over the last years, is related to a "circular" or "tautological" approach, which focuses on the features of an investment rather than conceptualizing it. Thirdly, there is a "closed-list" definition of investment. Fourthly, there are techniques that exclude certain assets and transactions from the definition. We consider that techniques 1 and 2 provide with a broad definition of investment, whereas techniques 3 and 4 tend to narrow the definition of investment and hence automatically reduce the scope of application of the BIT. ${ }^{19}$

\section{$\underline{\text { Technique } 1}$}

\footnotetext{
${ }^{18}$ Chaisse Julien and Bellak Christian (2011) 'Do Bilateral Investment Treaties Promote Foreign Direct Investment? Preliminary Reflections on a New Methodology' 3(4) Transnational Corporations Review 311, p.7.

${ }^{19}$ Chaisse-Bellak, Comment on the definition of Investment in BIT.
} 
Most BITs of the last 10 years have continued to adopt a broad "asset-based" definition of "investment", the scope of which goes beyond covering only FDI. The definition covers "every kind of asset" or "any kind of asset and a list of examples. Such lists usually include five categories of assets (as in Article 1 of the Vietnam-Netherland BIT):

1. Movable and immovable property as well as any other rights in rem in respect of every kind of asset;

2. Rights derived from shares, bonds and other kinds of interests in companies and joint ventures;

3. Title to money, to other assets or to any performance having an economic value;

4. Rights in the field of intellectual property, technical processes, goodwill and know-how;

5. Rights granted under public law, including rights to prospect, explore, extract and win natural resources.

However, because of the risk of an overbroad interpretation of what constitutes investment, various restrictions on a wide approach can be introduced into the scope and definition clause. In the first place, certain specific assets could be excluded from the definition as can be seen in the Vietnam-Mozambique BIT. Other approach is to define covered investment as every kind of assets but then restrict protection only to particular type of investments (BIT Vietnam-Romania and BIT Vietnam-German). Other approaches can restrict protection only to direct investments, i.e. every kind of asset connected with economic activities acquired for the purpose of establishing lasting economic relations (BIT Vietnam-Denmark). An additional requirement is that only investments made in accordance with host country law could be given protection. In this way, investments that fail to abide by the law of the host country, as applied upon entry and establishment, will lose the protection of the IIA, as they do not qualify as protected investments due to their illegality. ${ }^{20}$ This way of restriction is used in so many BITs that Vietnam signed with other countries such as the BIT Vietnam-Czech Republic, VietnamCambodia, Vietnam-Lavia, Vietnam-Australia, Vietnam-Cuba... These definitions, therefore, is deemed to be narrow instead of broad in the BIT index that we built for our research.

\section{Technique 2}

${ }^{20}$ OECD Investment Definition, p.10. 
Definition of "investment" can be flexible enough to apply to new types of investment that might emerge in the future. Some countries have responded to this need by introducing a tautological (or circular) definition of "investment". Numerous BITs concluded by the United States illustrate this approach, such as the BIT with Bahrain (1999). It defines an "investment" as "every kind of investment". This tautological approach is virtually limited to US BITs. ${ }^{21}$ None of the BITs that Vietnam signed with other countries that we reviewed use this technique.

\section{$\underline{\text { Technique } 3}$}

Third approach that has emerged to avoid an excessively broad definition of "investment" is what is called a "closed-list" definition. It consists of an ample, but finite list of tangible and intangible assets as can be seen in the Vietnam-Bulgaria BIT.

\section{Technique 4}

The last technique excludes certain sectors from the definition of investment. Technique 4 and 1 can be combined as in the Vietnam-Mozambique BIT.

\section{Admission vs. Establishment: Admission = 1, establishment $=2$}

Access limitations imposed on foreign investment have been justified on economic, social, political or national security grounds. BITs negotiation has evolved within this context, 2 models:

OPTION 1: One makes the admission/establishment subject to the domestic laws of the host country called the "admission clause" model

- "The right to be admitted" is entitled the host state, which frames its Model BIT with such admission provisions as "shall admit", "in accordance with local legislation".

- It allows the host country to apply any admission and screening mechanism for foreign investment that it may have in place and therefore to determine the conditions on which foreign investment will be allowed to enter the country

OPTION 2: the other grants foreign investors a right of establishment, although not in an absolute manner called the "right of establishment" model

\footnotetext{
${ }^{21}$ Chaisse, BITSel Research Memo, page. 4.
} 
- Right of establishment consists in providing foreign investors with NT + MFN treatment not only once the investment has been established, but also with respect to the establishment (entry)

- NT and MFN extended to the entry

- Investors of one party will receive treatment not less favourable with regard to investing in the territory of the other party

- than domestic investors (NT)

- and investors of any other third country (MFN)

These treaties aim at liberalizing investment flows

\section{National Treatment: Yes $=2$, No $=1$}

Essentially, NT requires that countries not discriminate against foreign investors in favour of domestic investors. The standard of treatment can be defined in two ways: "same" or "as favourable as" treatment or "no less favourable" treatment than the treatment they grant to investments of their own investors. The difference is subtle, but the "no less favourable" formulation leaves open the possibility that investors may be entitled to treatment that is more favourable than that accorded domestic investors, in accordance with international standards. Often the definition of NT is qualified by the inclusion of the provision that it only applies in "like circumstances" or "similar circumstances". With the situations of foreign and domestic investors often not being identical, this language obviously leaves room for interpretation. Not all BITs address the NT scope in the same manner. The first group does not deal with the issue at all. The second group, that of the majority, provides NT, but limits its coverage to established investments only (admission). A third group of agreements provides NT to the investors in the pre- and post-establishment phase (right of establishment).

\section{Most Favoured Nation Clause: Yes $=2$, No $=1$}

A first option consists of a drafting which gives the MFN a broad scope of application as in the Article 4 Treatment Argentina-Spain BIT (1991) which has been the provision of the Argentina-Spain BIT that led the tribunal in Maffezini. A second option limits the scope of the MFN clause through the inclusion of different possible restrictions.

Example: 
Neither Contracting Party shall in its territory subject investments or returns of nationals or companies of the other Contracting Party to treatment less favourable than that which it accords to its own nationals or companies or to nationals or companies of any third State. (BIT VN-UK)

\section{Fair and Equitable Treatment: Yes $=2$, No $=1$}

Thus, FET offers high protection when included in treaties. The FET favours FDI flows, while no FET (as in Pakistan-Turkey) might be less encouraging.

\section{Example:}

Investments of nationals or companies of each Contracting Party shall at all times be accorded fair and equitable treatment and shall enjoy full protection and security in the territory of the other Contracting Party. (BIT VN-UK)

\section{Direct and Indirect Expropriation coverd: Yes=2; No=1}

There are significant discrepancies in countries practices as some BITs will cover both direct and indirect expropriation while some will not address indirect expropriation. It is not a matter of national investment policies as some countries do not always cover indirect expropriation in their BITs. The choice is important as if indirect expropriation is covered by a treaty, it means that the BIT grant a protection to foreign investors who may be faced with serious alterations of the investment climate which they could not have reasonably anticipated.

\section{Example:}

Investments of nationals or companies of either Contracting Party shall not be nationalised, expropriated or subjected to measures having effect equivalent to nationalisation or expropriation (hereinafter referred to as "expropriation") in the territory of the other Contracting Party except for a public purpose related to the internal needs of that Party on a non-discriminatory basis and against prompt, adequate and effective compensation. (BIT VN-UK)

\section{Free transfer of investment-related funds: Yes=2; No=1}


A broad guarantee to allow outward transfers is likely to attract FDI while exception to the principle have to be considered as being relatively less encouraging to FDI. Indeed, from the foreign investors' point of view, these clauses are key in investment-treaties, as the ability to freely repatriate funds can be an important factor in their investmentdecision process. Developing countries, on the other hand, often have an interest in not restraining their ability to adopt certain restrictive exchange rate or other measures, for instance, as means to prevent or confront economic and financial crises.

Yes $=2$ means:

No limitation even in exceptional financial and economic circumstances (BIT Denmark Vietnam) or Only after tax obligation fulfillment (BIT VN-Bulgaria)

No $=1$ means:

"subject to its laws and regulations" (in this case, need to refer to Vietnamese Law on the transfer of funds of foreign investment $\rightarrow$ less beneficial for foreign investors)

A Contracting Party shall, when requested by a national of the other Contracting Party, and subject to its right in exceptional financial or economic circumstances to exercise equitably and in good faith powers conferred by its law (BIT Austria - Vietnam)

\section{Non-economic standards: $Y e s=1 ; \mathrm{No}=2$}

Because BITs grant strong protection to investors of either state party who is operating in the territory of the other party they may impinge upon human rights enforcement and realization in several ways. Therefore, states may face conflicting international legal obligations under the two regimes. As a result a BIT without any such provision may be considered as having great impact on FDI flows whereas any provision in a BIT seeking to protect human rights, environment, etc. may be considered as having a lower impact...

\section{Example:}

The Contracting Parties recognize that it is inappropriate to encourage investment by investors of the other Contracting Party by relaxing environmental measures. To this effect each Contracting Party should not waive or otherwise derogate from such environmental measures as an encouragement for the establishment, acquisition or expansion in its Area of investments by investors of the other Contracting Party. (BIT VN-Japan) 


\section{Investor-State Dispute Mechanism: $Y e s=2$, No $=1$}

An investor State dispute mechanism is an incentive to invest because it provides as an ultimate resort access to international (neutral) jurisdiction. If such a mechanism is included in the BIT, it can be expected to have a positive effect on FDI flows, but if it is subject to conditions, the effect is expected to be less.

(NO: If there is requirement to resort to local remedies or local tribunals or courts as a condition to submit to international tribunal or court).

\section{Umbrella clause: $Y e s=2$, No $=1$}

Because an umbrella clause extends the scope of the application of a BIT, it offers more protection to the investor. Our index makes the distinction between the IIAs with an umbrella clause and those who do not entail such a favourable protection granted to the investor and its investment. An umbrella clause can be drafted in different ways as shown below with the same legal consequences.

Example: Most European model BITs, should they include such a clause, do so within the article on promotion and protection of investment. The clause usually reads as follows: "Each contracting party shall observe any obligation it may have entered into with regard to investments of nationals or companies of the other contracting party"

\section{Temporal scope of application: Short $=1$, Long $=2$}

Either the treaty protection is extended to investments made before the entry into force of the agreement, or the coverage is restricted to the future, which suggests that the effect is likely to be less positive.

Short $=1$ : Only after the date of entry into force of BIT

\section{Long = 2: No limitation}

+ It is still Long if the Agreement excludes all the disputes, claims or differences arose from investments before the date of entry into force of the BIT.

i.e. BIT VN-Finland, VN-Cambodia

+ It is still Long even the scope of application has the limitation on the time/date/year (even before the entry into force of the BIT) that the BIT takes effect, such as: This agreement shall apply to all investments made after 1 January 1986 (even it was signed in 1991) 


\section{APPENDIX 2: PRINCIPAL COMPONENT ANALYSIS}

As mentioned and clarified by Kolenikov 's papers, Principal Component Analysis (PCA) solves the problem of the directions of the greatest variance of the linear combinations of $\mathrm{x}$ 's with $\mathrm{x}$ to be a random vector of dimension $\rho$ with finite $\mathrm{p} \times \mathrm{p}$ variance - covariance matrix $V[x]=\Sigma$. For that purpose, PCA tries to find out the orthogonal set of coefficient vectors $\mathrm{a}_{1}, \ldots . \mathrm{a}_{\mathrm{k}}$ such that:

$$
\begin{gathered}
a_{1}=\arg \underbrace{\max }_{\substack{a:\|a\|=1 \\
\ldots \ldots}} V\left[a^{\prime} x\right] \\
a_{k}=\arg \underbrace{\max }_{\begin{array}{r}
a:\|a\|=1 \\
a \perp a_{1}, \ldots a_{k-1}
\end{array}} V\left[a^{\prime} x\right]
\end{gathered}
$$

The linear combination $a_{k}^{\prime} x$ is regarded as the k-th principal component (PC). What is mentioned by Kolenikov is that the motivation behind this problem is that the directions of greatest variability give "most information" about the configuration of the data in multidimensional space

The solution to the above equation is found by solving the eigenproblem for covariance matrix $\Sigma$ with the values of $\lambda^{\prime}$ s and a's (given the identification condition $\|a\|=1$ ):

$$
\Sigma a=\lambda a
$$

What will be found as the solution for this above equation is the set of principal component weights a (referred as factor loadings), the linear combination a'x (referred as scores - these are also the values of components) and the eigenvalues $\lambda_{1} \geq \lambda_{2} \ldots \geq \lambda_{p}$ 


\section{APPENDIX 3: FURTHER RESULTS}

Table 10: Summary Statistics of Other Variables

\begin{tabular}{|c|c|c|c|c|c|}
\hline Variable I & obs & Mean & Std. Dev. & Min & M \\
\hline $\begin{array}{r}\text { crisisaffe it } \\
\text { crisisaffe vnt } \\
\text { wto_it } \\
\text { wto_vnt } \\
\text { open_it }\end{array}$ & $\begin{array}{l}557 \\
557 \\
557 \\
557 \\
458\end{array}$ & $\begin{array}{l}.1795332 \\
.032316 \\
.8850987 \\
4398564 \\
104.4273\end{array}$ & $\begin{array}{l}.3841432 \\
.1769969 \\
.3191894 \\
.4968157 \\
83.93618\end{array}$ & $\begin{array}{r}0 \\
0 \\
0 \\
0 \\
16.86355\end{array}$ & 440.432 \\
\hline $\begin{array}{r}\text { open_vnt } \\
\text { asean_it } \\
\text { inflation_it } \\
\text { inflation_vnt }\end{array}$ & $\begin{array}{l}458 \\
557 \\
549 \\
540\end{array}$ & $\begin{array}{r}133.5121 \\
2351885 \\
4.351548 \\
8.22963\end{array}$ & $\begin{array}{l}28.56535 \\
.4244978 \\
8.305652 \\
6.575313\end{array}$ & $\begin{array}{r}74.83472 \\
0 \\
-4 \\
-2\end{array}$ & 174.48 \\
\hline $\begin{array}{r}\text { diffinflat junt } \\
\text { logbruegel it } \\
\text { logbruegel vnt } \\
\text { taxrate_it } \\
\text { taxrate_vnt }\end{array}$ & $\begin{array}{l}532 \\
499 \\
505 \\
305 \\
313\end{array}$ & $\begin{array}{r}7.035714 \\
4.592806 \\
4.644471 \\
40.9541 \\
38.51118\end{array}$ & $\begin{array}{l}8.522301 \\
.1338287 \\
.0709139 \\
14.83477 \\
2.689135\end{array}$ & $\begin{array}{r}0 \\
3.934003 \\
4.527139 \\
14 \\
33\end{array}$ & $\begin{array}{r}5.0867 \\
4.7697 \\
1\end{array}$ \\
\hline $\begin{array}{l}\text { telephone_it } \\
\text { telephone_vnt } \\
\text { internet_it } \\
\text { internet_vnt } \\
\text { logairport _it }\end{array}$ & $\begin{array}{l}549 \\
521 \\
549 \\
540 \\
518\end{array}$ & $\begin{array}{r}35.81421 \\
9.380038 \\
40.51002 \\
16.2963 \\
12.00166\end{array}$ & $\begin{array}{r}21.71342 \\
5.74201 \\
30.41511 \\
13.89495 \\
1.677873\end{array}$ & $\begin{array}{r}0 \\
1 \\
0 \\
0 \\
7.151485\end{array}$ & 16.127 \\
\hline $\begin{array}{r}\text { logairport _vnt } \\
\text { prsrq_it } \\
\text { prsrq_vnt } \\
\text { prscc_it } \\
\text { prscc_vnt }\end{array}$ & $\begin{array}{l}557 \\
366 \\
420 \\
366 \\
420\end{array}$ & $\begin{array}{l}10.96682 \\
.8272404 \\
.6184524 \\
.6009016 \\
.4085476\end{array}$ & $\begin{array}{l}.5441005 \\
.1752487 \\
.0853589 \\
.2182872 \\
.1320828\end{array}$ & $\begin{array}{r}10.20729 \\
.27 \\
.36 \\
.17 \\
.25\end{array}$ & 1.862 \\
\hline $\begin{array}{l}\text { prsva_it } \\
\text { prsva_vnt } \\
\text { prsge_it } \\
\text { prsge_vnt } \\
\text { prsrl_it }\end{array}$ & $\begin{array}{l}36 \overline{6} \\
420 \\
366 \\
420 \\
366\end{array}$ & $\begin{array}{r}.8188251 \\
.3175 \\
.8151366 \\
.7920219\end{array}$ & $\begin{array}{r}.2013774 \\
.0558868 \\
.2188472 \\
0 \\
.1842519\end{array}$ & $\begin{array}{l}.17 \\
.17 \\
.25 \\
.5 \\
.33\end{array}$ & \\
\hline prsr1_vnt | & 420 & .6959048 & .0590084 & .67 & \\
\hline
\end{tabular}

Table 11: Results for test for including time dummies

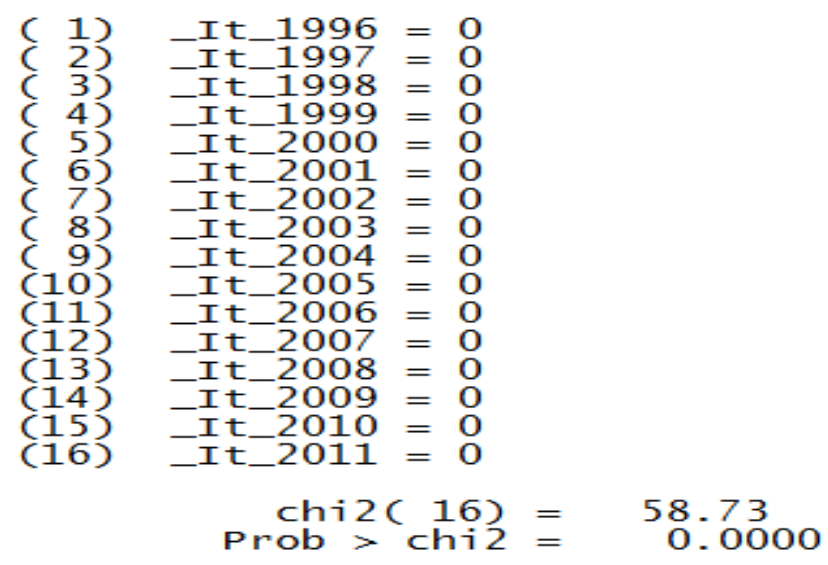

For this test, we can see that Prob $>$ chi $2=0$. This means we reject the null H0 that all years coefficients are jointly equal. Due to such existence of not-jointly-equal-0, including time dummies are necessary. 
Table 12: Results for Hausman test for Random effect vs. Fixed effect

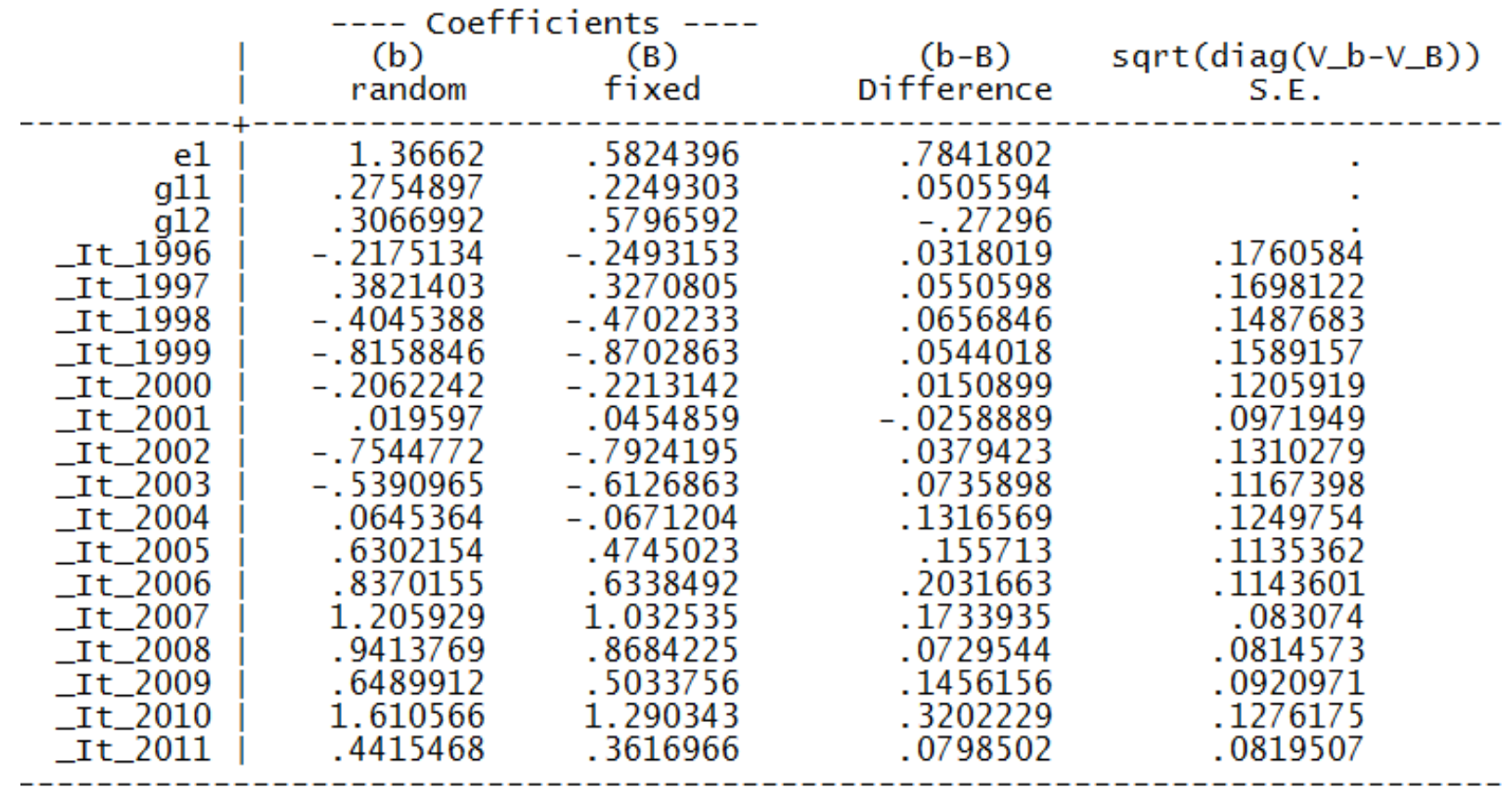

$\mathrm{b}=$ consistent under $\mathrm{Ho}$ and $\mathrm{Ha}$; obtained from xtreg

$\mathrm{B}=$ inconsistent under $\mathrm{Ha}$, efficient under Ho; obtained from xtreg

Test: Ho: difference in coefficients not systematic

$$
\begin{array}{rlrl}
\operatorname{chi} 2(19) & = & (b-B) & {\left[\left(V_{-} b-V \_B\right) \wedge(-1)\right](b-B)} \\
& = & 23.21 \\
\text { Prob>chi2 } & = & 0.2284 \\
\text { (V_b-V_B is } & \text { not positive definite) }
\end{array}
$$

For this test, we can see that Prob $>$ chi $2=0.2284>0.1$. This means we couldn't reject the null HO. In this case, Random Effect is considered to be better than Fixed Effect.

Table 13: Results for Breusch-Pagan Lagrange multiplier (LM): (Random effect vs. OLS)

$$
\begin{aligned}
& f[i d, t]=x b+u[i d]+e[i d, t] \\
& \text { Estimated results: } \\
& \begin{array}{rrr} 
& \text { Var } & \text { sd }=\operatorname{sqrt}(\operatorname{Var}) \\
\mathrm{f} & 7.249565 & 2.692502 \\
\mathrm{e} & 2.14205 & 1.463575 \\
\mathrm{u} & 1.937985 & 1.392115
\end{array}
\end{aligned}
$$

Test: $\quad \operatorname{var}(u)=0$

$$
\begin{aligned}
\text { chibar2 }(01) & =660.96 \\
\text { Prob }>\text { chibar2 } & =0.0000
\end{aligned}
$$

For this test, we can see that Prob $>$ chibar2 $=0$. This means we reject the null H0. In this case, Random Effect is better than simple regression of OLS. 
Table 14: List of countries for All, New and Old members sample*

\begin{tabular}{|c|c|c|c|}
\hline & Member (36) & New member (9) & Old member (27) \\
\hline 1 & AUSTRALIA & & $\mathrm{V}$ \\
\hline 2 & AUSTRIA & & $\mathrm{V}$ \\
\hline 3 & BELGIUM & & $\mathrm{V}$ \\
\hline 4 & BULGARIA & & $\mathrm{V}$ \\
\hline 5 & CAMBODIA & $\mathrm{V}$ & \\
\hline 6 & CHINA & & $\mathrm{V}$ \\
\hline 7 & $\mathrm{CZECH}$ & & $\mathrm{V}$ \\
\hline 8 & DENMARK & & $\mathrm{V}$ \\
\hline 9 & EGYPT & & $\mathrm{V}$ \\
\hline 10 & ESTONIA & & $\mathrm{V}$ \\
\hline 11 & FINLAND & $\mathrm{V}$ & \\
\hline 12 & FRANCE & & $\mathrm{V}$ \\
\hline 13 & GERMANY & & $\mathrm{V}$ \\
\hline 14 & HUNGARY & & $\mathrm{V}$ \\
\hline 15 & ICELAND & & $\mathrm{V}$ \\
\hline 16 & INDIA & $\mathrm{V}$ & \\
\hline 17 & INDONESIA & & $\mathrm{V}$ \\
\hline 18 & ITALY & & $\mathrm{V}$ \\
\hline 19 & JAPAN & $\mathrm{V}$ & \\
\hline 20 & KOREA & & $\mathrm{V}$ \\
\hline 21 & $\mathrm{LAO}$ & $\mathrm{V}$ & \\
\hline 22 & LUXEMBOURG & & $\mathrm{V}$ \\
\hline 23 & MALAYSIA & & $\mathrm{V}$ \\
\hline 24 & NETHERLANDS & & $\mathrm{V}$ \\
\hline 25 & PHILIPPINES & & $\mathrm{V}$ \\
\hline 26 & POLAND & & $\mathrm{V}$ \\
\hline 27 & ROMANIA & & $\mathrm{V}$ \\
\hline 28 & RUSSIA & & $\mathrm{V}$ \\
\hline 29 & SINGAPORE & & $\mathrm{V}$ \\
\hline 30 & SLOVAKIA & $\mathrm{V}$ & \\
\hline 31 & SPAIN & $\mathrm{V}$ & \\
\hline 32 & SWEDEN & & $\mathrm{V}$ \\
\hline 33 & SWITZERLAND & & $\mathrm{V}$ \\
\hline 34 & THAILAND & & $\mathrm{V}$ \\
\hline 35 & UAE & $\mathrm{V}$ & \\
\hline 36 & UNITED KINGDOM & $\mathrm{V}$ & \\
\hline
\end{tabular}

(*See 5.2 for further information about All, New, Old members sample) 
Table 15: Results for FDI controlling for Macro-economic variables

\begin{tabular}{|c|c|c|c|c|}
\hline & \multicolumn{4}{|c|}{ LogFDIivnt } \\
\hline & (1) & (2) & (3) & (4) \\
\hline \multirow[t]{2}{*}{ BITindex $_{\text {ivnt }}$} & $1.383 * * *$ & $1.233 * * *$ & $1.206 * *$ & $2.811 * *$ \\
\hline & $(0.450)$ & $(0.446)$ & $(0.479)$ & $(1.292)$ \\
\hline \multirow[t]{2}{*}{$\log g d p_{i t}$} & $0.294 *$ & $0.333 * *$ & $0.282^{*}$ & $0.360 * *$ \\
\hline & $(0.152)$ & $(0.153)$ & $(0.159)$ & $(0.172)$ \\
\hline \multirow[t]{2}{*}{$\operatorname{Loggd} p_{v n t}$} & $0.777 * * *$ & $0.922 * * *$ & $1.156 * * *$ & -0.372 \\
\hline & $(0.190)$ & $(0.183)$ & $(0.229)$ & $(0.333)$ \\
\hline \multirow{2}{*}{ Logdistant $_{i v n}$} & $-0.819 * *$ & $-0.814^{* *}$ & $-0.800 *$ & $-0.781^{*}$ \\
\hline & $(0.370)$ & $(0.379)$ & $(0.417)$ & $(0.459)$ \\
\hline \multirow[t]{2}{*}{ Contig $_{i v n}$} & -1.334 & -1.342 & -1.562 & -0.670 \\
\hline & $(1.197)$ & $(1.193)$ & $(1.314)$ & $(1.699)$ \\
\hline \multirow[t]{2}{*}{ Inflation $_{\text {it }}$} & -0.0130 & & & \\
\hline & $(0.00939)$ & & & \\
\hline \multirow[t]{2}{*}{ Inflation $_{v n t}$} & 0.0224 & & & \\
\hline & $(0.0190)$ & & & \\
\hline \multirow[t]{2}{*}{ Diffinflationi $_{v n t}$} & & 0.0125 & & \\
\hline & & $(0.0156)$ & & \\
\hline \multirow[t]{2}{*}{ Logexchangrate $_{i t}$} & & & 0.578 & \\
\hline & & & $(0.812)$ & \\
\hline \multirow[t]{2}{*}{ Logexchangrate $_{\text {vnt }}$} & & & -0.436 & \\
\hline & & & $(1.281)$ & \\
\hline \multirow[t]{2}{*}{$\operatorname{Tax}_{i t}$} & & & & $-0.0361 * *$ \\
\hline & & & & $(0.0141)$ \\
\hline \multirow[t]{2}{*}{$\operatorname{Tax}_{v n t}$} & & & & 0.00135 \\
\hline & & & & $(0.0416)$ \\
\hline$O b$. & 532 & 532 & 499 & 305 \\
\hline No. Id & 68 & 68 & 64 & 67 \\
\hline Timedummies & No & No & No & No \\
\hline
\end{tabular}

(Dependent variable is Natural logarithm of FDI from country i to Vietnam at year t. The panel technique of Random effect is applied. Id denotes country i - vietnam. ***/**/* present significant level of t-statistics at $1 \% / 5 \% / 10 \%$ level.) 
Table 16: Results for FDI controlling for Infrastructure variables

\begin{tabular}{|c|c|c|c|c|}
\hline & \multicolumn{4}{|c|}{ LogFDIivnt } \\
\hline & (1) & (2) & (3) & (4) \\
\hline \multirow[t]{2}{*}{ BITindex $_{\text {ivnt }}$} & $1.198 * *$ & $1.120 * *$ & $1.175 * * *$ & $1.087 * *$ \\
\hline & $(0.470)$ & $(0.503)$ & $(0.426)$ & $(0.492)$ \\
\hline \multirow[t]{2}{*}{$\log g d p_{i t}$} & $0.285 * *$ & $0.274 *$ & 0.0802 & -0.140 \\
\hline & $(0.128)$ & $(0.142)$ & $(0.288)$ & $(0.255)$ \\
\hline \multirow[t]{2}{*}{$\operatorname{Loggd} p_{v n t}$} & 0.323 & 0.231 & $2.502 * * *$ & -1.892 \\
\hline & $(0.216)$ & $(1.037)$ & $(0.635)$ & $(1.306)$ \\
\hline \multirow[t]{2}{*}{ Logdistant $_{i v n}$} & $-1.026 * * *$ & $-0.864 * *$ & $-1.017 * * *$ & $-1.236 * * *$ \\
\hline & $(0.346)$ & $(0.362)$ & $(0.362)$ & $(0.307)$ \\
\hline \multirow[t]{2}{*}{ Contig $_{\text {ivn }}$} & -1.021 & -1.041 & -1.356 & -1.082 \\
\hline & $(1.174)$ & $(1.201)$ & $(0.931)$ & $(0.940)$ \\
\hline \multirow[t]{2}{*}{ Telephone $_{i t}$} & 0.0258** & & & 0.0151 \\
\hline & $(0.0107)$ & & & $(0.0128)$ \\
\hline \multirow[t]{2}{*}{ Telephone $_{v n t}$} & $0.0856 * * *$ & & & $0.106 * * *$ \\
\hline & $(0.0257)$ & & & $(0.0282)$ \\
\hline \multirow[t]{2}{*}{ Internet $_{i t}$} & & 0.0131* & & $0.0135 *$ \\
\hline & & $(0.00717)$ & & $(0.00757)$ \\
\hline \multirow[t]{2}{*}{ Internet $_{v n t}$} & & 0.0161 & & $0.133 * * *$ \\
\hline & & $(0.0395)$ & & $(0.0372)$ \\
\hline$O b$. & 513 & 534 & 518 & 461 \\
\hline No.Id & 70 & 71 & 67 & 67 \\
\hline Timedummies & No & No & No & No \\
\hline
\end{tabular}

(Dependent variable is Natural logarithm of FDI from country i to Vietnam at year t. The panel technique of Random effect is applied. Id denotes country i - vietnam. ***/**/* present significant level of t-statistics at $1 \% / 5 \% / 10 \%$ level.) 
Table 17: Results for FDI controlling for Institutional variables

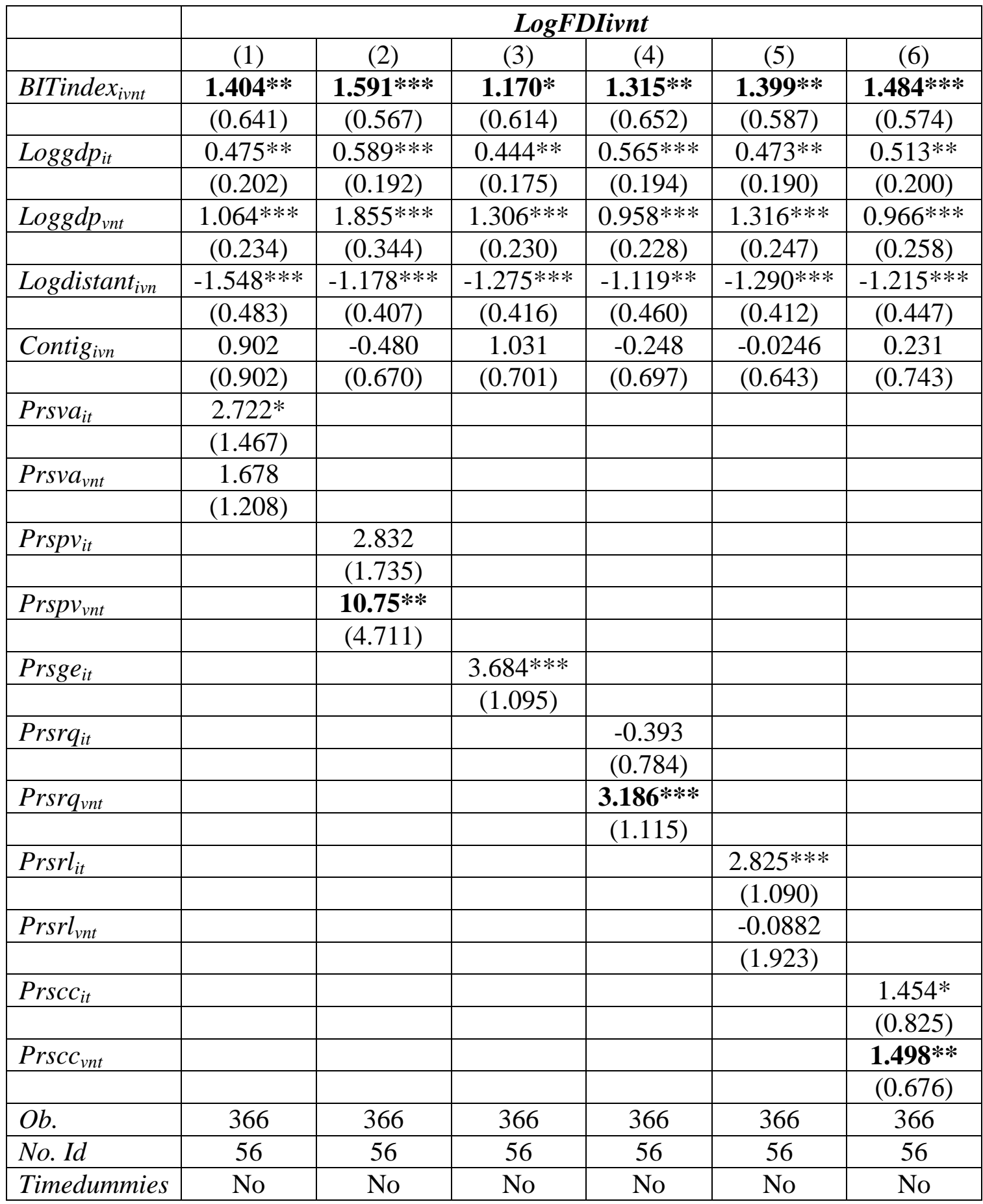

(Dependent variable is Natural logarithm of FDI from country $i$ to Vietnam at year t. The panel technique of Random effect is applied. Id denotes country i - vietnam. ***/**/* present significant level of $\mathrm{t}$-statistics at $1 \% / 5 \% / 10 \%$ level.) 